\title{
Monotheisme Yahudi Kuno dan Doktrin Trinitas
}

\author{
Deky Hidnas Yan Nggadas \\ Sekolah Tinggi Teologi Huperetes, Batam \\ deky_nggadas@yahoo.com
}

\begin{abstract}
This study examines ancient Jewish monotheism and compares it with the doctrine of the trinity in the Bible, particularly in Paul's epistles (Ephesians) and the Gospel of John. Researchers used qualitative methods with an emphasis on biblical studies. Researchers conclude that triadic patterns are central to Paul's theology in Ephesians. On the other hand, from the point of view of the practice of worship and devotion, early Christianity seemed to be dominated by a binitarian or diadid pattern of worship (as Hurtado argues). Was the Holy Spirit worshiped in the worship practices and devotion of early Christianity? The evidence from the NT forces us to refrain from giving positive answers to this question. This does not mean that the Holy Spirit is not presented as God (cf. John 14-16; etc.), but that the objects of recipients of worship and devotion in the NT pages are dominated by the Father and the Son. This pattern of worship finds its background not in the Greco-Roman religions, but in ancient Jewish monotheism. From ancient Jewish monotheism too, we find reference to the Christology of divine identity which was so dominant in the NT.
\end{abstract}

Keywords: Monotheism, Trinity, Exegesis, Ephesians

Abstrak: Penelitian ini mengkaji tentang monoteisme Yahudi kuno dan membandingkannya dengan doktrin trinitas dalam Alkitab, khususnya dalam surat Paulus (Surat Efesus) dan juga Injil Yohanes. Peneliti menggunakan metode kualitatif dengan menitikberatkan pada kajian biblika. Peneliti menyimpulkan pola-pola triadik merupakan pusat teologi Paulus dalam Surat Efesus. Di sisi lain, dari segi praktik penyembahan dan devosinya, Kekristenan mula-mula tampaknya didominasi oleh pola penyembahan yang binitarian atau diadik (seperti argumentasi Hurtado). Apakah Roh Kudus disembah dalam praktik penyembahan dan devosi Kekristenan mula-mula? Bukti-bukti dari PB memaksa kita untuk menahan diri dalam memberikan jawaban positif terhadap pertanyaan ini. Hal ini tidak berarti bahwa Roh Kudus tidak dipresentasikan sebagai Allah (bnd. Yoh. 14-16; dll.), namun memang objek penerima penyembahan dan devosi dalam halaman-halaman PB didominasi oleh Bapa dan Anak. Pola penyembahan ini, mendapatkan latar belakangnya bukan dalam agama-agama Greco-Roman, melainkan dalam monotheisme Yahudi kuno. Dari monotheisme Yahudi kuno juga, kita mendapati acuan bagi Kristologi identitas ilahi yang sangat dominan dalam PB.

Kata Kunci: Monoteisme, Trinitas, Eksegesis, Efesus

\section{Pendahuluan}

Penelitian ini diawali dengan mengutip James M. Renihan, Professor of Historical Theology di Institute of Reformed Baptist Studies:

Teologi tidak muncul di dalam sebuah ruang hampa (vacuum). Ia berkembang keluar dari situasi-situasi kehidupan yang nyata. Orang mempelajari Firman Allah, 
merenungkan pengajarannya, dan mengekspresikan kesimpulan-kesimpulan mereka. Sering kali kondisi-kondisi kehidupanlah yang memaksa mereka untuk memikirkan dengan lebih teliti (closely) dan lebih jelas (clearly) tentang pandangan-pandangan doktrinal mereka dan yang menajamkan ekspresi-ekspresi kebenaran. ${ }^{1}$

Kesimpulan ovservasi Profesor Renihan di atas memang tidak bisa disangkal, bahkan ketika kita bicara tentang doktrin sepenting doktrin Tritunggal yang merupakan "salah satu doktrin paling penting dalam iman Kristen," 2 atau doktrin yang dalam kata-kata Herman Bavinck, merupakan "the heartbeat of the Christian religion" ("denyut jantung agama Kristen"). ${ }^{3}$

Dari sejarah, kita mengetahui bahwa belum pernah ada formulasi doktrinal yang resmi mengenai Allah Tritunggal hingga Konsili Nicea (325 M). ${ }^{4}$ Persisnya, kita mendapati peran besar Athanasius, Bishop dari Aleksandria ( $\pm 296-373$ M) dalam Kontroversi Arian yang memicu diadakannya Konsili Nicea. ${ }^{5}$ Di dalam Konsili Nicea, kesetaraan hakikat/esensi (homoousia) Bapa, Anak, dan Roh Kudus ditegaskan, namun harus diakui bahwa rumusan ini sendiri tidak menjawab seluruh persoalan yang terimplikasi dari Kontroversi Arian. Salah satunya, seperti yang dicatat oleh Dunzl: "Apakah Bapa, Anak dan Roh Kudus adalah tiga entitas yang berbeda atau hanya satu entitas?"6

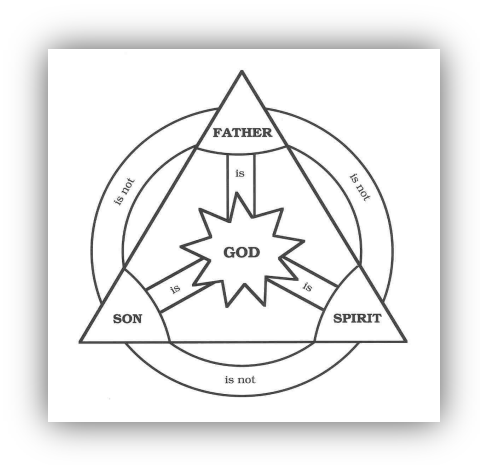

${ }^{1}$ James M. Renihan, Associational Churchmanship: Second London Confession of Faith 26.12-15, Volume 2 of Recovering Our Confessional Heritage (Palmdale, CA.: Reformed Baptist Academic Press, 2016), 90.

2 Wayne Grudem, Systematic Theology: An Introduction to Biblical Doctrine (Epub Version; Grand Rapids, Michigan: Zondervan, 1994), loc., 187/1083.

3 Herman Bavinck, Reformed Dogmatics, Volume Two: God and Creation, trans. John Vriend (Epub Version; Grand Rapids, Michigan: Eerdmans, 2004), loc., 197/516.

4 Bahkan istilah "Tritunggal" atau "Trinitas" (Trinity) sendiri tidak muncul di dalam Alkitab. Pada abad kedua, seorang Bapa Gereja bernama Teofilus dari Antiokhia pada akhir abad kedua menggunakan istilah

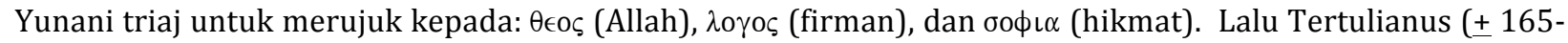
220 M) yang menulis dalam bahasa Latin, menggunakan istilah Trinitas yang sampai hari ini digunakan sebagai istilah teknis (terminus technicus) untuk berbicara mengenai Allah Tritunggal.

5 Poin di atas memiliki implikasi penting dalam persebaran informasi sejarah yang salah mengenai Pengakuan Iman Nicea. Misalnya, telah beredar luas pernyataan-pernyataan Irena Handono (seorang mualaf yang katanya mantan biarawati) bahwa "Yesus baru diangkat menjadi Tuhan dalam Konsili Nicea," yang implikasinya adalah bahwa Konsili tersebut diadakan dengan tujuan untuk merumuskan ke-Tuhanan Yesus. Pernyataan Irena Handono di sini tidak memiliki dasar historis sama sekali dan hanya boleh dianggap sebagai celotehan seorang pseudo-historian (sejarahwan abal-abal) yang secara sengaja memberikan informasi yang menyesatkan untuk mendapatkan penerimaan dari komunitas iman yang baru yang ia masuki. Tetapi, pada level kenyataan, memang informasi semacam ini telah beredar luas bahkan ditelan mentah-mentah oleh orang-orang non Kristen sebagai dasar untuk memperkuat penolakan mereka terhadap ke-Tuhanan Yesus secara khusus dan doktrin Tritunggal secara umum.

Berbicara secara historis, Konsili Nicea diadakan karena munculnya Arius bersama para pengikutnya yang mengajarkan bahwa Yesus memiliki esensi (hakikat) yang tidak setara dengan hakikat Bapa. Dalam pengertian tertentu, menurut Arius, Yesus dapat dianggap sebagai allah (a god), namun hanya Bapa yang memiliki hakikat keallahan yang sejati, sebab ada masa dimana Yesus bukan Allah (" there once was when He was not"). Ajaran inilah yang menimbulkan kontroversi dimana salah satu partisipan utama yang menolak pandangan Arius adalah Athanasius. Kontroversi ini diselesaikan melalui konsili yang diadakan pada bulan Juni tahun 325 M atas inisiatif Kaisar Konstantinus. Singkatnya, Konsili Nicea tidak pernah diadakan dengan tujuan untuk mengangkat Yesus menjadi Tuhan. Konsili itu diadakan karena adanya ajaran sesat, yaitu Arianisme. Untuk ulasan sejarah yang lebih detail mengenai konteks yang melahirkan Konsili Nicea, lih. Franz Dunzl, A Brief History of the Doctrine of the Trinity in the Early Church, trans. Jown Bowden (New York: T\&T Clark, 2007), khususnya Chapter 5: The Concern of Arius of Alexandria and the Reaction of His Opponents dan Chapter 6: The Intervention of Emperor Constantine and the Council of Nicaea.

6 Dunzl, A Brief History of the Doctrine of the Trinity in the Early Church, 61. 
Bapa Gereja yang berjasa dalam memberikan jawaban signfikan terhadap pertanyaan tersisa dari Konsili Nicea di atas adalah Gregorius Nazianzus (329-390 M) yang merupakan salah satu dari tiga Bapak Kapadokia (Capadocian Fathers; Basilius Agung, Gregorius dari Nisa, dan Gregorius Nazianzus). Bersama Basilius Agung, Gregorius Nazianzus memberikan kepada kita formulasi paling ringkas namun representatif mengenai doktrin Tritunggal: mia ouvsia treij u’postaseij (Satu Esensi/Hakikat, Tiga Pribadi). ${ }^{7}$ Saya kira, formulasi ini mewakili inti penting dari doktrin Tritunggal yang diterima Kekristenan ortodoks sampai hari ini, yaitu bahwa Allah Alkitab adalah Allah yang Esa dalam hakikat/esensi-Nya (ousia) dengan Tiga Pribadi yang berbeda (hypostasis). ${ }^{8}$

Jadi, seperti yang dikemukakan Renihan di atas, "situasi-situasi kehidupan yang nyata," dalam hal ini munculnya ajaran-ajaran yang ditemukenali Bapa-bapa Gereja sebagai ajaran menyimpang yang mendorong mereka untuk memikirkan dan merefleksikan ajaran Alkitab mengenai Allah lalu memformulasikannya dalam bentuk doktrin yang hari ini kita kenal dengan sebutan doktrin Tritunggal atau Trinitas.

\section{Metode Penelitian}

Pada penelitian ini, penulis atau peneliti menggunakan pendekatan atau metode kualitatif untuk memperoleh data yang valid guna membangun sebuah teori yang berkaitan dengan tema atau pokok penelitian. Metode kualitatif yang dimaksud adalah mengkaji dan mengelaborasi setiap sumber, informasi dan data-data yang diperoleh dari pustaka.

\section{Hasil dan Pembahasan Bukan Dogmatika; Bukan Apologetika}

Kita tentu saja bersyukur Tuhan memimpin Gereja untuk terus memberikan jawabanjawaban doktrinal mengenai Allah Tritunggal yang muncul dalam berbagai tahap sejarah hingga kini. Hari ini, kita tidak kekurangan ulasan dogmatik atau sistematiknya dalam buku-buku dogmatika atau teologi sistematika. Setiap buku teologi sistematika atau dogmatika yang terbit, sudah bisa dipastikan ada bagian di dalamnya yang membahas tentang doktrin ini.

Meski demikian, kita tidak dapat berpuas diri atas kenyataan itu karena tantangan bahkan penolakan terhadap doktrin Tritunggal selalu terekspresi dalam setiap tahap sejarah, termasuk dalam konteks kita sekarang. Dari dalam Kekristenan sendiri, telah muncul kesadaran yang bisa dikatakan universal bahwa dalam pengertian tertentu, formulasi doktrinal mengenai Allah Tritunggal tidak terdapat di dalam baik PL maupun PB. Misalnya teolog Reformed asal Belanda yang terkenal, Herman Bavinck, di satu sisi menyatakan: "Benih-benih yang berkembang menjadi kuntum bunga pewahyuan Trinitarian PB telah tertanam di dalam PL," namun pada empat paragraf setelah menuliskan klaim ini, Bavinck mengakui: "Kitab Suci tidak memberikan sebuah dogma

\footnotetext{
${ }^{7}$ Gregory Nazianzen, Orations, XXI, 35.

8 Itulah sebabnya, Gregorius Nazianzus dijuluki “Teolog Trinitarian” karena dialah yang memberikan artikulasi paling jelas mengenai Allah Tritunggal. Lih. Brian E. Daley, Gregory of Nazianzus (London and New York: Routledge, 2006), 41-50, khususnya hlm. 41-42. Juga mengenai Gregorius Nazianzus, W.C. Weinrich, "Gregory of Nazianzus," in Walter A. Elwell (ed.), Evangelical Dictionary of Theology (Grand Rapids, Michigan: Baker, 1995), 486-487, menulis bahwa Gregorius Nazianzus adalah alat Tuhan yang menghancurkan Arianisme dan menegakan pengakuan iman Nicea bahkan ia merupakan tokoh sentral pasca Konsili Nicea yang memberikan ekspresi doktrinal paling jelas mengenai Tritunggal bagi Ortodoksi Kristen hingga sekarang.
} 
Trinitarian yang dikembangkan secara penuh namun memberikan kepada kita bahan mentahnya."9

Selain itu, doktrin Tritunggal memang an sich [!] (pada dirinya sendiri) bersifat sungguh amat kompleks (rumit). ${ }^{10}$ Memang menyatakan bahwa doktrin ini bersifat kompleks tidak harus berarti bahwa doktrin ini salah, sebab kompleksitas itu sendiri merupakan implikasi logis dari keberadaan Allah yang sempurna dan transenden, sebagaimana yang diingatkan Agustinus: "Si comprehendis non est Deus" ("Jika Anda dapat memahaminya secara sempurna, Dia pasti bukan Allah."). ${ }^{11}$ Kompleks (rumit) tidak harus berarti salah; sederhana (simple) tidak harus berarti benar! ${ }^{12}$

Akan tetapi berkiblat kepada klaim Agustinus di atas, tidak serta merta meniadakan kesulitan yang maha besar itu dari segala upaya untuk making sense akan doktrin ini. Itulah sebabnya, teolog sekaliber Karl Barth, ketika menyendiri dalam ruang belajarnya untuk mempersiapkan materi kuliah mengenai Tritunggal di Gottingen yang terkenal hingga kini (1922-1924), dilingkupi oleh kesadaran akan kesulitan itu sehingga ia berguman demikian: "Dapatkah saya melakukannya?"13

Maka kita tidak heran bahwa dalam sejarah, dari dalam tubuh Kekristenan sendiri, ada pihak-pihak tertentu, di satu sisi, tergoda untuk membuang unitas (kesatuan) esensi Allah lalu jatuh ke dalam kecenderungan Tritheistik, dan di sisi lain, ada pihak-pihak tertentu yang membuang pluralitas Pribadi Allah lalu mengusung pandangan yang Unitarian dimana salah satu bentuk terkininya, selain persebarannya melalui para Saksi Yehovah, adalah Oneness Pentecostalism. ${ }^{14}$ Berbagai analogi yang pernah diusulkan dalam sejarah untuk mempermudah orang memahami doktrin ini pun, meski bernilai dalam taraf tertentu, pada akhirnya diakui bahwa tak satu pun yang tidak memiliki kelemahan. ${ }^{15}$

Penolakan yang lebih menantang dari luar Kekristenan akan Trinitas berasal dari teologi Islam dan Yudaisme. Di sini saya hanya fokus kepada tantangan dari teologi Islam. Bukan merupakan rahasia lagi bahwa terdapat retorika resistensif yang sangat kuat secara instrinsik dalam jantung teologi Islam terhadap doktrin Trinitas. Klausa pertama dari Syahadat: "Tiada Tuhan selain Allah," (bnd. Qs. 2:255; 59:22-23) memberikan empasis yang sangat kuat dan eksklusif terhadap keesaan Allah. Klausa ini bukan hanya afirmatif, yaitu menegaskan apa yang harus diimani oleh para penganutnya (Muslim), melainkan sekaligus mengintonasikan resistensi (penolakan) terhadap semua ajaran ketuhanan dari agama lain. Mengenai hubungannya dengan doktrin Tritunggal dalam Kekristenan sendiri,

${ }^{9}$ Bavinck, Reformed Dogmatics, Volume Two: God and Creation, loc., 197/516.

${ }^{10}$ Alister E. McGrath, Christian Theology: An Introduction (Epub version; $5^{\text {th }}$ ed.; West Sussex: Blackwell Publishing, Ltd., 2011), loc., 238/516, menulis: “Doktrin Trinitas merupakan salah satu aspek paling sulit dalam Teologi Kristen."

11 Lih. Jean Grondin, "Augustine's 'Si Comprehendis, Non Est Deus': To What Extent Is God Incomprehensible?," Analecta Hermeneutica, Vol. 9 (2017): 1-13.

12 Saya sering mendengar para apologet Muslim yang menyatakan: "Doktrin Allah Kristen itu rumit; Tawhid itu sederhana, sedemikian sederhananya hingga dapat dipahami anak kecil."

13 Bnd. Roberth Letham, Allah Trinitas dalam Alkitab, Sejarah, Theologi, dan Penyembahan, terj. Lanna Wahyuni (Surabaya: Momentum, 2004), ix.

14 Mengenai Oneness Pentecostalism, V. Synan, "Pentecostalism," in Walter A. Elwell (ed.), Evangelical Dictionary of Theology (Grand Rapids, Michigan: Baker, 1995), 837-838, menjelaskan bahwa Gerakan Pantekostalisme yang awal kemunculannya pada tahun 1901, mengalami perpecahan doktrinal pada tahun 1911 di Los Angeles dimana Glen Cook dan Frank Ewart menolak doktrin Tritunggal dan mengajarkan bahwa Yesus adalah pribadi yang sama dengan Bapa dan Roh Kudus dan bahwa baptisan air hanya sah dilakukan dalam nama Yesus (itulah sebabnya, gerakan ini dinamai juga "Jesus Only" atau "Oneness") yang diikuti dengan pengalaman berbahasa Roh (Glosalalia). Dengan formulasi semacam ini, Oneness Pentecostalism bisa dianggap sebagai reformulasi (formulasi ulang) ajaran bidat Monarkhianisme atau Sabelianisme atau Modalisme yang sudah mulai muncul pada Abad Kedua namun baru mendapatkan bentuknya yang solid dalam ajaran modalistik dari Sabelius dari Roma pada awal Abad Ketiga.

15 Mengenai analogi-analogi tersebut, lih. Millard J. Erickson, Christian Theology (Epub version; $3^{\text {rd }}$ ed.; Grand Rapids, Michigan: Baker Academic, 2013), loc., 209/981-211/981. 
Ludwig W. Adamec, Profesor Emiritus di School of Middle East and North African Studies, University of Arizona, dalam buku: Historical Dictionary of Islam, khususnya pada entri "Allah," (nama Sesembahan Islam) menulis bahwa konsekuensi dari dua kalimat Syahadat tersebut adalah: "Tidak ada Trinitas, atau Anak Allah". ${ }^{16}$ Franz Dunzl, Professor of Early Church History and Patristics at the University of Würzburg, Jerman, menulis:

Tepat karena pengakuan akan keesaan Allah, Qur'an menyanggah secara energetik (energetically) melawan doktrin Trinitas Kristen.... Dari perspektif Islam, doktrin Trinitas merupakan sebuah kesesatan yang berbahaya (a dangerous error) yang menjauhkan seseorang dari monotheisme.... ${ }^{17}$

Patut dicatat bahwa dalam teologi Islam, dosa yang tidak terampuni adalah dosa syirik, yaitu dosa mengasosiasikan sesuatu atau seseorang dengan Allah. Kekristenan dianggap mengidap dosa mematikan ini karena menyembah Yesus, dan karena itu mengasosiasikan manusia - mereka percaya bahwa Yesus hanyalah seorang nabi, tidak lebih - dengan Allah yang Esa. Bahkan dalam sejumlah bagian, Allah Qur'an tampaknya mengajarkan bahwa Kekristenan menyembah tiga Allah, yaitu Allah, Yesus, dan Maria (QS. 4:71; 5:17, 72-73, 116). Dan karena itu, Kekristenan dianggap telah jatuh ke dalam kubangan Politheisme.18

Meskipun terdapat detail-detail doktrinal yang berbeda antara Yudaisme dan Islam, namun kedua agama besar ini berbagian dalam asumsi yang sama mengenai doktrin Trinitas Kristen. James D.G. Dunn, Profesor PB (emeritus) di University of Durham, menyatakan:

Status yang disepakati atau yang disematkan bagi Yesus adalah kunci distinktif dan yang mendefinisikan fitur Kekristenan. Hal ini juga merupakan batu sandungan terbesar bagi dialog antar-iman antara orang-orang Kristen dan Yahudi, dan antara orang-orang Kristen dan Muslim. Orang-orang Yahudi dan Muslim tidak dapat menerima status keilahian Yesus sebagai Anak Allah, yang dianggap oleh orang-orang Kristen sebagai sesuatu yang fundamental bagi iman mereka. Pemahaman Kristen

${ }^{16}$ Ludwig W. Adamec, Historical Dictionary of Islam (2 ${ }^{\text {nd }}$ ed.; Lanham: Scarecrow Press, Inc., 2009), 29.

17 Dunzl, A Brief History of the Doctrine of the Trinity in the Early Church, 2. Komentar saya terhadap Dunzl adalah bahwa mungkin kata yang tepat bukan "secara energetik," melainkan "secara militan" (militantly) atau "agresif" (aggressive) atau "kombatif" (combative). Sejarah intimidasi, penganiayaan, bahkan pembunuhan terhadap orang-orang Kristen di Negara-negara Timur Tengah yang mayoritas Muslim, salah satunya disebabkan karena keyakinan orang-orang Kristen akan Trinitas. Publikasi hasil riset terbaru mengenai isu ini, dilakukan oleh: Raymond Ibrahim, Crucified Again: Exposing Islam's New War on Christians (Washington, DC.: Regnery Publishing, Inc., 2013).

18 Ekspresi-ekspresi janggal dari Allah Qur'an mengenai Trinitas dalam bagian-bagian di atas menimbulkan kecurigaan serius mengenai integritas Allah Qur'an dalam merepresentasikan posisi ortodoksi Kristen mengenai Trinitas. Kekristenan tidak pernah percaya Tiga Allah; tidak pernah menggunakan formulasi "Allah adalah Yesus" sebaliknya "Yesus adalah Allah"; tidak pernah percaya bahwa sebutan "Anak Allah" bagi Yesus berarti bahwa kelahiran Yesus merupakan buah dari sebuah hubungan biologis; tidak pernah percaya bahwa Maria adalah salah satu pribadi ilahi. Robert Spencer, The Truth about Muhammad: The Founder of the World's Most Intolerant Religion (Washington, DC: Regnery Publishing, Inc., 2006), 114, menilai bahwa ekspresi-ekspresi janggal ini "Mendemonstrasikan pemahaman yang kabur akan doktrin Kristen mengenai Trinitas". Bahkan ekspresi-ekspresi janggal tersebut tidak lebih dari sebuah misrepresentasi atau miskarakterisasi yang dalam istilah logika disebut straw men fallacy. Lih. James R. White, What Every Christian Needs to Know about the Qur'an (Minneapolis, Minnesota: Bethany Publishing House, 2013), khususnya Chapter 4: "Say Not Three": The Qur'an and the Trinity. Senada dengan Spencer, White juga percaya bahwa misrepresentasi Qur'an terhadap doktrin Trinitas Kristen memperlihatkan bahwa penulisnya tidak lain adalah Muhammad yang salah memahami isi doktrin ini.

Di Indonesia, baru-baru ini, celotehan dari Egy Sudjana yang mengkontraskan keyakinan akan keesaan Allah dengan Trimurti (Hinduisme) dan Trinitas (Kristen) mengekspresikan misrepresentasi Qur'an di atas terhadap doktrin Trinitas dalam Kekristenan. 
mengenai Allah sebagai Trinitas membingungkan mereka. Menganggap Yesus sebagai pribadi ilahi, yang layak menerima penyembahan sebagai Allah, tampak bagi mereka sebagai sesuatu yang jelas merupakan penolakan terhadap keesaan, dan lebih merupakan suatu bentuk politheisme ketimbang suatu bentuk monotheisme. ${ }^{19}$

Saya akan kembali ke komentar Dunn di atas. Namun saya ingin melanjutkan diskusi ini bahwa ketidakpahaman akan doktrin Trinitas juga melahirkan beragam argumen absurd yang beredar luas di kalangan kaum awam maupun di internet. Dua di antaranya yang paling umum adalah, pertama, tudingan bahwa doktrin Tritunggal tidak "lolos" dalam saringan matematika tingkat paling dasar - orang-orang Kristen dianggap "tidak dapat melakukan penjumlahan" (mis. $1+1+1=1$ ?); ${ }^{20}$ dan kedua, bahwa doktrin ini merupakan sebuah kontradiksi logis. Mungkin figur paling representatif yang secara blak-blakan mengemukakan klaim bernada olokan yang menggemakan kedua tudingan umum ini, adalah Thomas Jefferson (1743-1824), Presiden Amerika Serikat yang ketiga. Jefferson menyebut doktrin Trinitas sebagai "kegilaan metafisik," yang menghambat kemajuan religius umat manusia karena doktrin ini "mengkumatkan kembali politheisme, dimana satu-satunya perbedaan doktrin ini dengan paganisme adalah bahwa doktrin ini lebih tidak masuk akal" dibandingkan paganisme. ${ }^{21}$ Alister E. McGrath, Professor of Science and Religion di Oxford University, mengomentari klaim olokan Jefferson, demikian: "Banyak orang yang akan tersenyum membaca kritikan [Jefferson] sambil berbagian dalam pandangannya."22

Sampai di sini, kita berhadapan dengan tiga pertanyaan krusial, sebagaimana yang telah dirangkum dalam sebuah buku yang telah saya kutip sebelumnya: Making Sense of the Trinity: 3 Crucial Questions dari Profesor Erickson. Ketiga pertanyaan tersebut, adalah: pertama, apakah doktrin Trinitas itu alkitabiah?; kedua, apakah doktrin ini masuk akal?; dan ketiga, apakah implikasi distinktif dari doktrin ini jika dibandingkan dengan ajaranajaran ketuhanan dari agama-agama lain. ${ }^{23}$

Ketiga pertanyaan di atas adalah pertanyaan-pertanyaan yang menarik, stimulatif, dan valid untuk dielaborasi. Tetapi, pertanyaan-pertanyaan itu, sebagaimana telah saya ulas di atas, lahir dalam pergulatan riset teologis yang menggunakan pendekatan atau perspektif dogmatika atau teologi sistematika termasuk pendekatan apologetika. Meskipun saya memberikan ulasan yang cukup panjang di atas yang menggambarkan kemunculan, kerumitan (kompleksitas), dan tantangan-tantangan yang ada di dalam maupun yang beriringan dengan doktrin Trinitas, namun saya tidak memaksudkan inti pembahasan mengenai Trinitas dalam Studium Generale ini dari perspektif teologi sistematika/dogmatika dan atau apologetika. Upaya semacam ini, seperti yang sudah saya indikasikan sebelumnya, telah sangat banyak dilakukan. ${ }^{24}$

19 James D.G. Dunn, Did the First Christians Worship Jesus?The New Testament Evidence (Louisville, Kentucky: Westminster John Knox Press, 2010), 1.

20 Millard J. Erickson, Making Sense of the Trinity: 3 Crucial Questions (Epub version; Grand Rapids, Michigan: Baker Academic, 2000), loc., 23/64.

${ }^{21}$ Dikutip dan diulas dalam: McGrath, Christian Theology: An Introduction, loc., 238/516.

22 McGrath, Christian Theology: An Introduction, loc., 238/516.

23 Lih. keseluruhan tulisan: Erickson, Making Sense of the Trinity: 3 Crucial Questions (Epub version).

24 Saya sengaja memberikan ulasan pengantar yang cukup panjang dan mencakup banyak aspek dalam kemunculan maupun perkembangan lebih lanjut dari doktrin Trinitas hingga kini dari perspektif teologi sistematika dan apologetika, karena dua alasan utama. Pertama, mengingat betapa pentingnya doktrin ini dalam iman Kristen, saya mempertimbangkan bahwa mayoritas mahasiswa yang mengikuti Studium Generale ini perlu diberikan pembekalan dasar mengenai inti penting dari formulasi doktrin Tritunggal yang menstimulasi tantangan maupun penolakan terhadapnya sejak kemunculannya sampai sekarang. Dan kedua, 


\section{Kombinasi Perspektif Sejarah dan Teologi Biblika}

Sebagaimana terindikasi pada tema Studium Generale ini: "Ancient Jewish Monotheism and the Doctrine of the Trinity," kita bisa melihat ada intonasi historis (Ancient Jewish Monotheism) dan sekaligus intonasi dogmatis (the Doctrine of the Trinity). Kombinasi ini memang secara sengaja saya lakukan demi memperlihatkan dua hal penting. Pertama, formulasi "Satu Hakikat, Tiga Pribadi" (Gregorius Nazianzus) yang pengertiannya adalah bahwa Ketiga Pribadi tersebut adalah Pribadi-pribadi yang berbeda satu sama lain (Bapa, Anak, dan Roh Kudus), setara dan esa di dalam hakikat keallahan, berada secara kekal, harmonis di dalam relasi intra-Trinitarian, merupakan sebuah formulasi yang baru dikembangkan di kemudian hari (yang dirumuskan secara resmi dalam Konsili Nicea, abad keempat). Dengan kata lain, Anda tidak mendapatkan formulasi ini secara eksplisit termaktub di dalam halaman-halaman Alkitab. ${ }^{25}$ Dan kedua, sebagaimana yang akan saya perlihatkan nanti, empasis-empasis para penulis Alkitab bisa dikatakan tidak memperlihatkan kesamaan empasis dengan formulasi doktrinal abad keempat yang bersifat ontologis, walau kita melihat nanti bahwa telah ada upaya (mis. penulis Injil Yohanes) untuk memperlihatkan bagaimana relasi antara Bapa dan Logos (Anak).

Di satu sisi, tanpa menyadari akan dua pokok penting di atas, kita akan terjebak pada pembacaan Trinitarian yang anakronistik terhadap data Alkitab, bahkan memberikan kesan yang misleading seakan-akan isu dan penekanan dalam perdebatan abad keempat merupakan isu dan penekanan dari para penulis Alkitab (khususnya PB). ${ }^{26}$

Sebuah ilustrasi nyata dari problem tersebut adalah sebutan "Anak Allah" bagi Yesus, yang dalam rumusan teologi sistematika maupun dalam benak banyak orang Kristen, sebutan itu selalu berarti bahwa "Yesus adalah Allah," Pribadi Kedua Allah Tritunggal. Setiap kali mereka membaca PB dan menemukan sebutan ini bagi Yesus, gambaran makna seperti itulah yang muncul di benak mereka. Namun pemaknaan seperti ini dilihat oleh para pakar PB sebagai pemaknaan yang lebih mewakili hasil perkembangan diskusi Kristologis di kemudian hari (anakronistik bahkan reduksionistik) ketimbang pemaknaan yang mewakili seluruh data PB yang kaya dan variatif mengenai penggunaan sebutan "Anak Alllah" bagi Yesus. Itulah sebabnya, James D.G. Dunn misalnya, mendorong kita

ulasan-ulasan saya mengenai isu ini dari perspektif sejarah dan teologi biblika akan terlihat jelas kontrasnya jika para peserta Studium Generale ini telah memiliki pemahaman dasar (basic knowledge) mengenai formulasi doktrin Tritunggal.

25 Satu contoh saja dari teks yang paling sering dirujuk untuk berbicara mengenai doktrin Trinitas, Matius 28:19 yang menyebutkan mengenai Bapa, Anak, dan Roh Kudus. Teks itu menyebutkan ketiga Nama itu begitu saja tanpa penjelasan apa pun mengenai: apakah ketiga Nama itu mewakili Tiga Pribadi yang berbeda atau sama?; bagaimana hubungannya satu sama lain?; Jika ketiga Nama itu adalah Pribadi-pribadi yang berbeda, apakah ketiga Pribadi tersebut setara secara hakikat?; apakah Ketiganya berada secara kekal secara bersama? Jadi, lontaran mengenai Bapa, Anak, dan Roh Kudus, hanya menyisakan lebih banyak pertanyaan ketimbang jawaban. Pertanyaan-pertanyaan semacam inilah yang digumuli oleh Bapa-bapa Gereja yang nantinya menghasilkan rumusan doktrinal sebagaimana yang terdapat dalam Konsili Nicea.

Selain itu perlu diberi catatan di sini bahwa 1 Yohanes 5:7-8 yang tampaknya jelas berbicara mengenai Trinitas merupakan teks yang sangat mungkin bukan merupakan bagian original dari naskah Surat 1 Yohanes. Bruce M. Metzger, A Textual Commentary on the Greek New Testament (4th ed.; New York: American Bible Society, 2002), 647, mempertimbangkan berbagai bukti tekstual yang ada, lalu mengomentari 1 Yohanes 5:7-8, demikian: “...these words are spurious and have no right to stand in the New Testament...."

26 Anakronisme berarti "tidak sesuai dengan jaman". Misalnya, Anda menyatakan "Rasul Paulus naik sepeda." Ini anakronistik karena pada masa Rasul Paulus, belum ada kendaraan yang bernama sepeda. Dalam konteks tema Studium Generale ini, perdebatan dengan penekanan ontologis yang muncul dalam rumusan doktrinal Konsili Nicea mengenai Trinitas, bukan merupakan isu yang menjadi perhatian dari para penulis PB. 
untuk selalu aware terhadap konteks para penulis dan pembaca mula-mula PB dimana sebutan tersebut lahir dan muncul pertama kali. ${ }^{27}$

Di sisi lain, kedua pokok penting di atas menstimulasi kita untuk mengajukan pertanyaan-pertanyaan historis yang mewakili konteks kelahiran Kekristenan yang nanti melahirkan tulisan-tulisan otoritatif, yang kita sebut PB. Premis utama yang diterima secara konsensus adalah bahwa Kekristenan lahir dalam konteks Yudaisme Bait Suci Kedua (Second Temple Judaisme) dan dunia Greco-Roman. Para pengikut awal Yesus adalah orangorang Yahudi, termasuk Paulus yang nantinya memberikan sumbangsih besar terhadap formulasi teologi Kristen, pun adalah orang Yahudi. ${ }^{28}$ Bertolak dari premis mendasar ini, kita perlu bertanya: "Bagaimana para penulis PB mengemukakan lontaran-lontaran yang menjadi benih perumusan doktrin Tritunggal di kemudian hari, namun tetap memandang diri mereka menyembah Allah yang esa?" Atau, bagaimana mungkin lontaran-lontaran itu tetap dianggap sebagai ekspresi penyembahan terhadap Allah yang esa dalam konteks Yudaisme Bait Suci Kedua? Apakah lontaran-lontaran berlatar belakang pada Yudaisme Bait Suci Kedua atau sebenarnya para penulis PB meminjam konsep-konsep Greco-Roman yang politheistik? Terlepas dari apa dan bagaimana kita menjawab pertanyaan-pertanyaan ini, penekanan penting dari pertanyaan-pertanyaan ini adalah keharusan untuk menempatkan diskusi mengenai tema ini dalam konteks abad pertama, bukan diskusi teologis abad keempat.

Guna menjawab pertanyaan-pertanyaan dari perspektif penyelidikan sejarah di atas, pertama-tama kita perlu memastikan lontaran-lontaran apa yang dikemukakan oleh para penulis PB mengenai Allah. Atau menggunakan istilah Bavinck yang sudah saya kutip sebelumnya, "bahan mentah" apa yang telah disiapkan para penulis Alkitab yang nantinya diramu menjadi "menu jadinya" (doktrin Trinitas) pada abad keempat. Dan untuk melakukan hal ini, saya akan menggunakan pendekatan Teologi Biblika (Biblical Theology). ${ }^{29}$ Khususnya pengamatan terhadap karakteristik penekanan kitab-kitab tertentu, yang karena keterbatasan waktu dan ruang, saya hanya akan fokus pada lontaranlontaran mengenai Allah dalam Surat Efesus dan Injil Yohanes. ${ }^{30}$ Saya memilih salah satu

27 James D.G. Dunn, Christology in the Making: An Inquiry into the Origins of the Doctrine of the Incarnation (2nd ed.; London: SCM Press, 1989), 12-13. Sebuah studi yang lebih luas mengenai penggunaan sebutan "anak Allah" dengan berbagai rujukan dan konteks, dengan penekanan khusus terhadap penggunaannya bagi Yesus, dilakukan oleh: D.A. Carson, Jesus the Son of God: A Christological Title Often Overlooked,Sometimes Misunderstood, and Currently Disputed (Epub version; Wheaton, Illinois: Crossway Books, 2012). Sub-judul dari buku ini juga ikut menggambarkan poin saya di atas.

28 Frank Thielman, The Theology of the New Testament: A Canonical and Synthetic Approach (Grand Rapids, Michigan: Zondervan, 2005), 219, menulis: "Secara tradisional, Paulus dianggap sebagai pangerannya para teolog." James D.G. Dunn, The Theology of Paul (Grand Rapids, Michigan: Eerdmans, 1998), 13, berargumentasi bahwa Paulus adalah teolog Kristen yang pertama dan yang terbesar!

${ }^{29}$ Bagi mereka yang mengenal baik pendekatan Teologi Biblika, mengetahui bahwa salah satu aspek penting dari pendekatan ini adalah aspek sejarah (historis). Meski demikian, pendekatan historis tidak harus merupakan pendekatan Teologi Biblika, walau pendekatan Teologi Biblika tidak dapat dilakukan tanpa mengasumsikan progresivitas sejarah pewahyuan. Itulah sebabnya, saya memisahkannya menjadi dua kategori pendekatan.

${ }^{30}$ Karya klasik yang memberikan gambaran penting mengenai pendekatan Teologi Biblika, ditulis oleh: Geerhardus Vos, Biblical Theology: Old and New Testaments ( $7^{\text {th }}$ ed.; Grand Rapids, Michigan: Eerdmans, 1971). Dalam perkembangannya hingga kini, pendekatan Teologi Biblika menggunakan tiga pendekatan spesifik, yaitu: pertama, menelusuri perkembangan sebuah tema yang mencakup baik PL maupun PB guna memperlihatkan bagaimana gagasan awal dari tema tersebut, kemudian perkembangannya dalam tulisantulisan yang lebih kemudian hingga klimaksnya dalam tulisan yang paling akhir dalam sejarah pewahyuan; kedua, mengamati sebuah tema spesifik dalam korpus tertentu atau kitab tertentu guna memperlihatkan distinktivitas maupun kemiripan penekanannya dengan kitab-kitab yang lain; dan yang ketiga, mengamati fenomena penggunaan tulisan penulis kitab yang satu dalam tulisan penulis kitab yang lebih kemudian. Pendekatan spesifik yang terakhir ini sering disebut: inner biblical exegesis atau intertextuality. Untuk contoh pendekatan spesifik yang pertama, lih. mis. Daniel L. Smith-Christopher, A Biblical Theology of Exile: Overtures to Biblical Theology (Minneapolis: Fortress Press, 2002); dan G.K. Beale and Mitchell Kim, God Dwells Among 
dari surat-surat Paulus (Surat Efesus) karena surat-surat Paulus merupakan dokumendokumen terawal dalam PB. Saya juga memilih Injil Yohanes karena kitab ini merupakan salah satu kitab yang muncul di periode terakhir PB. ${ }^{31}$ Dengan demikian, kita bisa melakukan perbandingan bagaimana lontaran-lontaran itu muncul pada periode paling awal hingga menjelang periode akhir PB.

\section{Pola-pola Triadik}

Sekali lagi, para penulis Alkitab, dalam hal ini para penulis PB tidak memberikan elaborasi yang lengkap, detail, dan penuh mengenai doktrin Tritunggal sebagaimana yang kita dapati dalam Konsili Nicea. Namun, kita memang mendapati "benih" atau "bahan mentah" untuk rumusan doktrinal tersebut di dalam PB.

Dua orang pakar yang nama mereka perlu disebutkan di sini yang dari mereka saya mendapatkan mayoritas materi untuk bagian ini - saya hanya memberikan beberapa suplemen - adalah Arthur W. Wainwright (Professor of New Testament Emeritus at Candler School of Theology, Emory University) dan Robert Letham (Professor of Systematic and Historical Theology at the Union School of Theology).

Wainwright melakukan studi menyeluruh mengenai data PB yang relevan dengan tema ini. Di dalam studinya, Wainwright mendapati bahwa para penulis PB memang memberikan lontaran-lontaran "rangkap tiga" (triadik atau ternary): Bapa (Allah), Anak (Yesus Kristus), dan Roh Kudus. Bagi Wainwright, penggunaan pola-pola triadik ini memperlihatkan adanya kesadaran mengenai pluralitas Pribadi-pribadi Allah, namun konteks belum "memaksa" mereka untuk memberikan formulasi-formulasi doktrinalnya. ${ }^{32}$

Bertolak dari hasil riset Wainwright, Letham mendokumentasikan satu bagian khusus untuk berbicara mengenai pola-pola triadik dalam Surat Efesus, yang akan saya kembangkan dalam sub-poin di bawah ini.

\section{Pola-pola Triadik dalam Surat Efesus: Sebuah Ulasan Eksegetis ${ }^{33}$}

Sangat menarik untuk dicermati mengenai kecenderungan di kalangan para teolog Paulus (Pauline theologians) yaitu ada semacam pengabaian terhadap pola-pola triadik di dalam tulisan-tulisan Paulus. Kita tidak sulit menemukan kecenderungan yang patut disesalkan ini karena hingga kini kita memiliki cukup banyak buku mengenai teologi Paulus. ${ }^{34}$ Jadi, ulasan pada bagian ini bisa dikatakan memberikan suplemen penting juga terhadap studi teologi biblika mengenai surat-surat Paulus, khususnya Surat Efesus.

Us: Expanding Eden to the Edens of the Earth (Downers Grove, Illinois: IVP, 2014). Untuk contoh pendekatan spesifik yang kedua, lih. mis. Bruce K. Waltke and Charles Yu, An Old Testament Theology: An Exegetical, Canonical, and Thematic Approach (Grand Rapids, Michigan: Zondervan, 2007); Thielman, The Theology of the New Testament: A Canonical and Synthetic Approach; George Eldon Ladd, A Theology of the New Testament (Revised Edition; Grand Rapids, Michigan: Eerdmans, 1993); Tomas R. Schreiner, New Testament Theology: Magnifying God in Christ (Grand Rapids, Michigan: Baker Academic, 2008); Dunn, The Theology of Paul; Thomas R. Scheiner, Paul Apostle of God's Glory in Christ: A Pauline Theology (Downers Grove, Illinois: IVP Academic, 2001); W.L. Telford, The Theology of the Gospel of Mark (Cambridge: Cambridge University Press, 1999); Darrell L. Bock, A Theology of Luke's Gospel and Acts (Biblical Theology of the New Testament; Grand Rapids, Michigan: Zondervan, 2011). Untuk contoh pendekatan spesifik yang ketiga, lih. mis. G.K. Beale and D.A. Carson (eds.), Commentary on the New Testament Use of the Old Testament (Grand Rapis, Michigan: Baker Academic, 2007).

31 Lih. D.A. Carson and Douglas J. Moo, An Introduction to the New Testament (2nd ed.; Grand Rapids, Michigan: Zondervan, 2005).

32 Arthur W. Wainwright, The Trinity in the New Testament (London: SPCK, 1962).

33 Saya tidak lagi memberikan ulasan pengantar ke dalam Surat Efesus namun langsung saja membahas pola-pola triadik dalam surat ini. Untuk ulasan introduktif mengenai Surat Efesus, lih. Carson and Moo, An Introduction to the New Testament, 479-496.

34 Kita bisa menyebut beberapa di antaranya: Herman Ridderbos, James D.G. Dunn, Thomas R. Schreiner, dll. 
Dalam memberikan ulasan eksegetis-ringkas terhadap bagian-bagian yang relevan dengan isu yang dibahas dalam Studium Generale ini, saya akan mengelompokkan teks-teks yang berbicara mengenai pola-pola triadik ke dalam tiga kelompok, yaitu teks-teks yang berkaitan dengan rencana keselamatan, kehidupan iman umat Allah, dan gereja atau jemaat. Selain itu, mengingat cukup banyak teks yang akan dibahas dalam bagian ini, maka penjelasan eksegetisnya lebih merupakan komentar rangkuman ketimbang penjelasan detail terhadap teks-teks tersebut.

\section{a. Pola Triadik dan Rencana Keselamatan}

Dua perikop yang akan dibahas di bawah topik ini, yaitu Efesus 1:3-14 dan 2:4-10. Kedua teks ini mengandung lontaran mengenai pola triadik dalam hubungan dengan rencana keselamatan Allah bagi umat-Nya.

\section{Efesus 1:3-14}

Jika kita memperhatikan terjemahan LAI-ITB, LAI-BIS dan juga terjemahan-terjemahan berbahasa Inggris, Efesus 1:3-14 merupakan sebuah perikop yang diterjemahkan dalam sejumlah kalimat yang ditandai dengan tanda titik. Padahal, di dalam bahasa aslinya, Efesus 1:3-14 merupakan satu kalimat utuh tanpa tanda pemisah kalimat (tanda titik). Bagian ini terdiri atas 202 kata dan merupakan kalimat terpanjang kedua setelah Kolose 1:9-20 (218 kata) yang juga merupakan satu kalimat tunggal di dalam teks Yunaninya. ${ }^{35}$ Mengenai teks ini, Larkin menyatakan bahwa meskipun para sarjana tidak sepakat mengenai bentuk struktural kalimatnya, namun mereka sepakat bahwa teks ini merupakan sebuah deklarasi eulogia (pujian berkat) atas karya Allah dalam rencana keselamatan bagi umat-Nya. ${ }^{36}$ Bukan hanya itu, William Hendriksen bahkan mengidentifikasi bahwa keseluruhan surat Efesus dapat dijelaskan berdasarkan akronim dari kata Yunani: euloge di mana setiap pasalnya mewakili sebuah huruf dari kata tersebut (E: eternal foundation - ps. 1; U: universal scope - ps. 2; L: lofty goal - ps. 3; 0: organic unity - ps. 4; G: glorious renewal - ps. 5; dan E: effective armor - ps. 6). ${ }^{37}$

Sampai di sini, kita bisa mengidentifikasi beberapa pokok yang menghubungkan pola triadik dalam teks ini dengan rencana keselamatan bagi umat Allah.

Pertama, karya Bapa (ay. 3-6). Dalam ayat 3, Paulus memuji Bapa karena Ia "telah mengaruniakan kepada kita segala berkat rohani di surga". Ungkapan pujian ini dikemukakan lagi dalam ayat 6 dan itu berarti ayat 3 dan 6 membentuk sebuah inclusio. ${ }^{38}$ Sekarang kita perlu mencermati gagasan apakah yang terkandung dalam "segala berkat rohani"39 yang telah dikaruniakan Bapa bagi kita.

a. Bapa "memilih" kita (ay. 4). Kata Yunani dari "memilih" dalam ayat ini adalah kata $\epsilon^{\prime} \xi \in \lambda \lambda^{\prime} \xi \alpha \tau$ (aorist indikatif medium, orang ketiga tunggal dari kata $\epsilon^{\prime} \kappa \lambda \epsilon^{\prime} \gamma \omega$ ). Di dalam

35 William J. Larkin, Ephesians: A Handbook on the Greek Text (Waco, Texas: Baylor University Press, 2009), 4.

36 Larkin, Ephesians: A Handbook on the Greek Text, 4. Latar belakang dari bentuk deklarasi berkat pujian ini kelihatannya berakar dalam formula Pujian bagi Allah di sinagoge di mana formula ini digunakan untuk mengucapkan berakah kepada Allah atas karya-Nya dalam penciptaan dan penebusan serta pemujaan terhadap segala kepenuhan Allah yang mengaruniakan kebaikan bagi umat-Nya. Lih. Ralph P. Martin, Ephesians, Colossians, Philemon (Interpretation: A Bible Commentary for Teaching and Preaching; Atlanta: John Knox Press, 1973), 13.

37 William Hendriksen, Galatians and Ephesians (New Testament Commentary; Edinburgh: The Banner of Truth Trust, 1969), 62-66.

38 Inclusio adalah fitur retorika di mana gagasan pada bagian awal diulangi lagi pada bagian akhir sebuah unit teks.

${ }^{39}$ Frasa "berkat rohani" muncul beberapa kali dalam surat Efesus $(1: 20 ; 2: 6 ; 3: 10 ; 6: 12)$ yang merujuk kepada realitas spiritual ke mana Kristus membawa umat-Nya. Lih. Sinclair B. Ferguson, Let's Study Ephesians (Edinburgh: The Banner Truth Trust, 2008), 7-8. 
konteksnya, pemilihan ini dilakukan oleh Bapa sebagai sumbernya; objeknya adalah "kita"; fondasi atau sarananya adalah Kristus; alasannya adalah kasih Allah; pemilihan itu terjadi dalam kekekalan; dan tujuannya adalah menjadikan kita milikNya yang tidak bercacat. Implikasinya, pemilihan ini dilakukan bukan karena kita sebagai alasannya, melainkan karena kehendak Allah sendiri sebagaimana yang nanti akan dijelaskan lebih lanjut di dalam ayat 5.40 Menurut John P. Heil, pemilihan ini terjadi bukan sebagai sebuah tindakan impersonal yang acak, melainkan terjadi atas suatu kerelaan personal yang agung dari Allah yang Ia lakukan secara bebas atau yang Ia lakukan seturut kerelaan kehendak-Nya sendiri bukan karena ada alasan lain di luar diri-Nya sendiri.41 Tindakan memilih itu terjadi sebelum penciptaan. Dengan demikian, pemilihan itu melampaui waktu. ${ }^{42}$ Pemilihan itu merupakan suatu keputusan oleh Bapa dan dalam hal ini kita tidak memiliki penjelasan apa pun. Sesuatu dengan kalimat yang sebelumnya, ini merupakan suatu keputusan yang dibuat "di dalam Kristus" - suatu realitas yang eksis bukan sekadar pada satu waktu tertentu di masa yang akan datang dalam sejarah dunia, atau dalam pengalaman hidup orang-orang tertentu, tetapi pada waktu pemilihan itu sendiri. ${ }^{43}$ Di bagian lain dalam PB, Anak mengklaim hak untuk memilih kita (Yoh. 16:15), demikian juga Roh Kudus memilih Saulu dan Barnabas untuk tugas misionaris yang digambarkan dalam Kisah Para Rasul (13:1). Akan tetapi, Paulus memandang pemilihan terutama sebagai karya Bapa, meskipun tidak terpisah dari Anak, di dalam Siapa Ia telah memilih kita, tidak juga dari Roh Kudus, yang adalah Dia oleh Siapa berkat itu datang (bnd. Ay. 3). ${ }^{44}$ Sesungguhnya, karena inilah yang pertama dari semuanya, maka seluruh berkat oleh Roh Kudus mengalir dari sini. Hal ini bisa kita pahami dengan jelas karena fakta bahwa tujuan dari pemilihan adalah agar kita menjadi kudus dan tidak bercacat di hadapan Bapa. ${ }^{45}$

b. Bapa "menetapkan" kita untuk menjadi umat-Nya (ay. 5). Kata "menetapkan" di sini dalam bahasa Yunaninya: proori,saj (partisip aorist aktif nominatif tunggal dari kata $\pi \rho o o \rho i \zeta(\omega)$. Bentuk partisip dari kata ini mengindikasikan bahwa kata "menetapkan" di sini merupakan penjelasan lanjutan dari kata "memilih" dalam ayat 4. Heil menyatakan bahwa "menetapkan" di sini mempertegas "memilih" dalam ayat 3.46 Allah "memilih" kita dengan cara "menetapkan" kita sejak kekekalan untuk diangkat (atau diadopsi) menjadi anak-anak-Nya. Pemilihan dengan cara penepatan itu terjadi di dalam Kristus sesuai dengan "kerelaan kehendak-Nya" (kedaulatan Allah sendiri). ${ }^{47}$ Bapalah yang menentukan kita dari semula melalui Sang Anak untuk

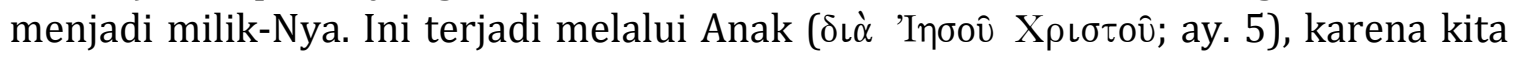
hanya dapat diangkat dalam persatuan dengan Sang anak yang alamiah. Kristus adalah Sang Anak dan kita dipilih dalam Dia sebagai anak-anak melalui pengangkatan. ${ }^{48}$ Jadi, pemilihan, penentuan dari semula, dan pengangkatan sebagai anak-anak-Nya, dibangun dalam hubungan antara Bapa dan Anak dalam kekekalan, suatu hubungan yang sepenuhnya memperhitungkan Roh Kudus melalui Siapa realitas-realitas ini digenapkan. ${ }^{49}$

${ }^{40}$ Lih. Hendriksen, Galatians and Ephesians, 74-78.

41 John P. Heil, Ephesians: Empowerment to Walk in Love for the Unity of All in Christ (Leiden: Brill, 2007), 59.

${ }^{42}$ Heil, Ephesians: Empowerment to Walk in Love for the Unity of All in Christ, 60.

43 Heil, Ephesians: Empowerment to Walk in Love for the Unity of All in Christ, 61.

${ }^{44}$ Hendriksen, Galatians and Ephesians, 76.

45 Larkin, Ephesians: A Handbook on the Greek Text, 5.

${ }^{46}$ Heil, Ephesians: Empowerment to Walk in Love for the Unity of All in Christ, 62.

47 Lih. Hendriksen, Galatians and Ephesians, 78-79.

48 rtin, Ephesians, Colossians, Philemon, 14.

${ }^{49}$ Martin, Ephesians, Colossians, Philemon, 14. 
Menurut Paulus, rencana keselamatan itu diinisiasi oleh Bapa yang memilih dan menetapkan kita menjadi anak-anak-Nya melalui Kristus supaya kita memuji Dia sebagaimana yang dilakukan Paulus dalam ayat 3 dan $6 .^{50}$ Dalam kaitan dengan Anak, Ia adalah Bapa: "Allah dan Bapa Tuhan kita Yesus Kristus" (ay. 3). Karena ini adalah hubungan-hubungan yang jelas dalam Allah, maka masuk akal untuk berkesimpulan bahwa Mereka adalah kekal. Gagasan ini diperkuat oleh referensi di ayat 4 mengenai pemilihan yang terjadi "sebelum dunia dijadikan." Bapa telah menggenapkan kovenan-Nya dengan Abraham. Kembali ke Kitab Kejadian, Allah berjanji untuk memberkati Abraham dan seluruh keturunannya - dalam kaitan dengan tanah dan keturunan, dan juga secara umum. Sekaran, "segala berkat rohani" telah diberikan, dalam penggenapan terhadap janji kuno itu. Berkat-berkat ini diberikan oleh Roh Kudus, karena berkat-berkat itu adalah berkatberkat "rohani". Istilah "berkat" dalam bentuk tunggal menunjukkan kesatuan dari suatu keseluruhan. Ini bukan berkat-berkat yang begitu berlainan dan tidak saling terkait, tetapi merupakan bagian dari suatu gerakan anugerah Allah yang dimulai dengan Abraham dan sekarang digenapkan "dalam Kristus". Frasa ini (en Christo) menunjukkan bahwa berkat Bapa diberikan oleh Roh Kudus dan di dalam Anak. Tidak heran, Martin menyatakan bahwa presentasi Paulus akan karya Bapa yang memilih dan menetapkan kita harus memimpin kita kepada doksologi (pujian pemujaan) terhadap Allah sebagaimana yang terungkap dalam konteksnya. ${ }^{51}$

Kedua, karya Kristus (ay. 7-12). Bagian ini berbicara mengenai karya penebusan Kristus yang menggenapkan rencana keselamatan Allah yang telah memilih dan menetapkan kita di dalam Dia. Kristus menunaikan tugas penebusan ${ }^{52}$ itu dengan cara mengucurkan "darah-Nya" dan olehnya rahasia ${ }^{53}$ keselamatan itu tersingkap bagi kita yaitu bahwa kita Allah karena kasih-Nya berkehendak menebus kita dengan cara mengampuni dosa kita atas dasar pengorbanan Kristus. ${ }^{54}$ Kita ditetapkan dari sejak kekekalan untuk ditebus oleh Kristus supaya kita disatukan di dalam Kristus sebagai Kepala (ay. 7-10).55 Karya penebusan Kristus adalah dasar pengharapan ${ }^{56}$ kita sekaligus dasar bagi kita untuk menaikan doksologi bagi Allah demi kemulian-Nya (ay. 11-12). Dalam Kristus, Sang Anak, kita menerima penebusan melalui darah-Nya. Oleh kuasa Allah, kita mendapatkan pembebasan dari perbudakan dengan pembayaran harga tertentu (ay. 7). Penebusan ini terjadi di salib. Kematian Kristus menjamin pembebasan kita. Sebagai pembayaran, penebusan itu hanya dapat dipersembahkan kepada Bapa, karena Iblis tidak memiliki hak

${ }^{50}$ Lih. Leslie J. Crawford, “Ephesians 1:3-4 and the Nature of Election," in The Master's Seminary Journal 11/1 (2000): 75-91.

51 Martin, Ephesians, Colossians, Philemon, 16-17.

52 Konsep penebusan di sini dari segi sejarah keselamatan berlatar belakang dari kisah kejatuhan dalam PL, kemudian bayangannya adalah penebusan Allah bagi Israel yang membebaskan mereka dari perbudakan di Mesir yang klimaksnya adalah pembebasan umat-Nya dari dosa melalui pengorbanan Kristus. Lih. Ferguson, Let's Study Ephesians, 14-15; Martin, Ephesians, Colossians, Philemon, 17.

53 Di dalam PB, istilah "rahasia" merujuk kepada rencana Allah yang kekal yang menjadi tersingkap melalui kedatangan serta karya penebusan Kristus. Lih. Ferguson, Let's Study Ephesians, 12-13.

54 Lih. Heil, Ephesians: Empowerment to Walk in Love for the Unity of All in Christ, 63.

${ }^{55}$ Lih. Heil, Ephesians: Empowerment to Walk in Love for the Unity of All in Christ, 62. Sebutan "Kepala" bagi Kristus di sini secara metaforik mengasumsikan otoritas Kristus atas umat-Nya yang adalah tubuh-Nya. Sebuah studi yang sangat komprehensif mengenai penggunaan istilah "kepala" dalam PB, dilakukan oleh: Wayne Grudem, "Does kefalh ('Head') Means 'Source” or 'Authority Over' in Greek Literature? A Survey of 2,366 Examples," in Trinity Journal 6.1 (1985): 38-59; Wayne Grudem, “The Meaning of Kefalh ('Head'): An Evaluation of New Evidence, Real, and Alleged," in Journal of Evangelical Theological Society 44:1 (March 2001): 25-65.

56 Pengharapan di sini berarti "kita memiliki pengharapan sebelum menikmati seluruh penggenapannya" termasuk "kita memiliki pengharapan ketika orang-orang lain tidak memilikinya karena mereka berada di luar Kristus". Lih. Andrew T. Lincoln, Ephesians (Software version of WBC Vol. 42; Dallas, Texas: Word Books, 1998). 
atau otoritas atas umat manusia. Sekali lagi, hubungan antara Bapa dan Anak ada dalam latar belakang, menggemakan komentar Paulus di Roma 8:32, di mana ia merujuk kepada Bapa yang tidak menyayangkan Anak-Nya, tetapi menyerahkan-Nya bagi kita semua, dan di Roma 4:25, di mana ia berkata bahwa Yesus "diserahkan" untuk disalibkan karena pelanggaran-pelanggaran kita.

Ketiga, karya Roh Kudus (ay. 13-14). Dalam kedua ayat ini, ada dua hal yang dirujuk sebagai karya Roh Kudus bagi kita sebagai umat Allah.

a. Roh Kudus memateraikan kita (ay. 13). Kata Yunani yang digunakan untuk karya Roh Kudus ini adalah kata '́ $\sigma \phi \rho \alpha \gamma i \sigma \theta \eta \tau \epsilon$ (aorist indikatif pasif, orang kedua jamak dari kata $\sigma \phi \rho \alpha \gamma i \zeta \omega)$. Menurut ayat ini, pemateraian oleh Roh Kudus itu terjadi ketika orang menjadi percaya kepada Kristus. Dalam konteks jaman itu, biasanya tanda materai itu digunakan untuk ternak-ternak dan para budak sebagai penanda kepemilikan seseorang. Jadi, orang-orang percaya dimateraikan oleh Roh Kudus berarti bahwa mereka ditandai dan dipelihara sebagai milik Allah hingga mendapatkan semua yang dijanjikan Allah bagi mereka (ay. 14). Tindakan pemateraian ini adalah tindakan yang sama yang disebut juga sebagai baptisan Roh Kudus. ${ }^{57}$ Roh, seperti yang telah dibahas sebelumnya, menggenapkan berkat yang dijanjikan kepada Abraham, dan dengan demikian aktif secara dinamis dalam semua unsur rencana Bapa yang telah dibahas juga sebelumnya. ${ }^{58}$ Tetapi, khususnya dalam aspek-aspek yang terdapat dalam ayat 13-14 ini, Ia tampil lebih menonjol. Kata kerja sphargizein berarti membubuhkan materai pada sesuatu entah untuk keamanan, atau menunjukkan kepemilikan, atau menjamin keautentikan. Gagasangagasan ini semua terkait erat. Tentu gagasan tentang keamanan begitu menonjol, dank arena itu mungkin dekat dengan maksud Paulus. Tindakan Roh Kudus ini terjadi bersamaan dengan iman - bentuk partisip aorist kemungkinan besar adalah suatu partisip dari keadaan waktu itu. Jika demikian, yang ingin Paulus tekankan bukanlah tindakan tertentu dari Roh Kudus, melainkan pribadi Roh Kudus itu sendiri yang memateraikan orang-orang percaya. ${ }^{59}$

b. Roh Kudus adalah jaminan kita (ay. 14). Istilah Yunani yang digunakan di sini adalah

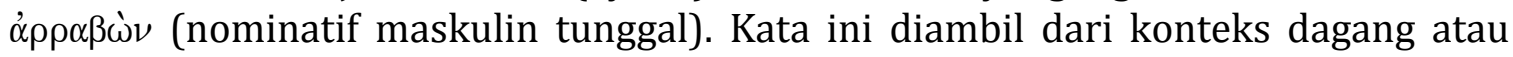
bisnis pada waktu itu yang merujuk kepada uang muka (down payment) yang dibayarkan sebagai jaminan akan pelunasan yang akan dilakukan di kemudian hari. ${ }^{60}$ Di sini, Paulus menggunakannya secara metaforik untuk merujuk kepada karya Allah yang memberikan Roh Kudus sebagai jaminan menuju penggenapa realisasi rencana Allah secara komplit di masa depan (bnd. 2Kor. 1:22; 5:5). ${ }^{61}$ Gordon D. Fee menyatakan bahwa istilah "jaminan" di sini berarti bahwa Roh Kudus menjadi penentu konsumasi di masa depan terhadap realitas keselamatan yang telah dinikmati pada masa kini. ${ }^{62}$ Dengan demikian, uang muka ini sama jenisnya dengan sisa pembayaran nanti. Uang muka ini menjamin bahwa sisanya pasti menyusul. Di sini yang dimaksud dengan warisan yang akan datang. Roh Kudus, yang memateraikan semua orang percaya, meneguhkan bahwa Bapa akan memberi mereka kepemilikan yang penuh atas warisan kekal mereka dalam Kristus. ${ }^{63}$

57 Lih. argumentasi eksegetisnya dalam: Lincoln, Ephesians [Software version].

58 Crawford, "Ephesians 1:3-4 and the Nature of Election," 87-88.

${ }^{59}$ Crawford, "Ephesians 1:3-4 and the Nature of Election," 89-90.

60 Lih. "avrrabwn," in Friberg Lexicon [Software version of BibleWorks6].

61 Lincoln, Ephesians [Software version].

62 Gordon D. Fee, God's Empowering Presence: The Holy Spirit in the Letters of Paul (Peabody, MA.: Hendrickson, 1994), 671.

63 Lincoln, Ephesians [Software version]. 
Argumen eksegetis di atas dapat diringkas demikian. Semua berkat Allah yang digambarkan dalam Efesus 1:3-14 merupakan karya Allah dalam kategori triadik. Bapa adalah sumber segala berkat yang kita terima dalam Kristus (ay. 3), di mana berkat yang pertama adalah pemilihan (ay. 4) dan predestinasi (ay. 5). Anak adalah Dia di dalam Siapa kita menerima penebusan (ay. 7), dan Dialah yang akan mengepalai segala sesuatu (ay. 10). Sesungguhnya, semua berkat Allah dari permulaan sampai akhir diberikan dalam Kristus, Sang Anak. Setiap unsur dalam seluruh kalimat diberikan "dalam Kristus" atau "dalam Dia". Roh Kudus adalah Dia yang memateraikan kita ketika kita percaya (ay. 13) dan yang menjamin warisan kita (ay. 14). Jadi seluruh panorama teologis ini menunjukkan gerakan yang berkesinambungan dari anugerah Allah kepada kita: dari Bapa, di dalam atau melalui Anak, dan oleh Roh Kudus. Menurut konglomerasi kalimat yang dahsyat ini, rencana keselamatan yang dijanjikan kepada Abraham, digenapkan oleh Kristus, merupakan janji Bapa, Anak, dan Roh Kudus bersama-sama, di mana Mereka dalam kesatuan yang tidak terpisahkan, sejak sebelum penciptaan dan sepanjang seluruh panorama sejarah manusia, menjami warisan kekal kita dalam Kristus.

Jadi, Efesus 1:3-14 berbicara tentang karya Bapa, Anak, dan Roh Kudus dalam rencana keselamatan. Karya tersebut dimulai dalam kekekalan, terealisasi dalam kekinian, dan terkulminasi di dalam kekekalan di masa depan. Dengan kata lain, keselamatan kita terjadi atas inisiasi Bapa, terjadi atas penebusan Kristus, dan tergenapi atas karya Roh Kudus. Inilah yang disebut Paulus sebagai Injil keselamatan yang sejati. Itulah sebabnya, Martin menyatakan bahwa dalam teks ini Paulus mengungkapkan pujian-Nya kepada Allah dalam Trinitarian layout (tata letak Trinitarian). ${ }^{64}$

\section{Efesus 2:4-10}

Agak sedikit berbeda dengan Efesus 1:13-14, teks ini (2:4-10) berbicara tentang rencana keselamatan Allah bagi umat-Nya dalam setting binitarian. ${ }^{65}$

Dalam Efesus 2:1-3, kita mendapati latar belakang dari pasal 2:4-10 yaitu kondisi manusia yang tidak berdaya serta tanpa pengharapan akibat belenggu dosa. Manusia hidup dalam kejahatan dari waktu ke waktu tanpa kemampuan serta pengharapan untuk melepaskan diri darinya. Martin Kitchen membagi kondisi manusia yang digambarkan di sini ke dalam tujuh karaktersitik:
a. Mati dalam pelanggaran-pelanggaran dan dosa-dosa (ay. 1);
b. Menaati penguasa-penguasa dunia (ay. 2);
c. Mengikuti jalan dunia (2:2);
d. Hidup dalam hawa nafsu dan kedagingan (2:3);
e. Memenuhi hasrat kedagingan dan pikiran jahat (2:3);
f. Menjadi orang-orang yang dimurkai Allah (2:3)
g. Tidak memiliki perbedaan hidup dengan orang lain (2:3). ${ }^{66}$

64 Martin, Ephesians, Colossians, Philemon, 14.

65 Dalam studi mengenai teologi PB, para ahli mengidentifikasi bahwa orang-orang Kristen mula-mula menyembah Yesus sama seperti mereka menyembah Bapa. Konsep ini disebut konsep Binitarian yaitu ada dua pribadi yang disembah dalam kesetaraan sebagai Allah. Lih. Larry W. Hurtado, "Worship, NT Christian," in Katherine Doob Shakenfeld (ed), The New Interpreter's Dictionary of the Bible (Nashville: Abingdon Press, 2006-2009), 910-923.

66 Martin Kitchen, Ephesians (New Testament Readings; London: Routledge, 1994), 56. 
Jadi latar belakang teks ini adalah kondisi umat manusia yang tidak berpengharapan dan sama sekali tidak berdaya sebagai akibat dosa. Paulus menggambarkan hal ini sebagai suatu kondisi "kematian", dari mana kita tidak mampu menyelamatkan diri kita sendiri. Hanya pertolongan dari luar yang dapat membantu, hanya pertolongan Allah sendiri. Dengan penuh rahmat, Allah bertindak dalam kuasa dan anugerah. Setelah menjelaskan kondisi manusia yang tanpa pengharapan itu, Paulus mengkontraskannya dengan karya keselamatan dari Allah yang "kaya dengan rahmat, oleh karena kasih-Nya yang besar, yang dilimpahkan-Nya” bagi kita (ay. 4). Dalam teks Efesus 2:4-10, kita mendapati dua gagasan utama yang berkaitan dengan karya Allah bagi keselamatan manusia, yaitu inti/fondasi keselamatan (ay. 4-7) ${ }^{67}$ dan penerimaannya oleh anugerah semata (8-10). ${ }^{68}$

Pertama, inti atau fondasi keselamatan (ay. 4-7). Di dalam bagian ini, Paulus mengkontraskan karya Allah yang mahakasih itu dengan kondisi kita yang sudah digambarkan sebelumnya, yaitu bahwa Allah "menghidupkan" kita dari kematian akibat dosa yang sejajar dengan karya-Nya yang "membangkitkan" kita.69 Karya Allah di sini merujuk kepada karya Bapa sebagaimana yang dikemukakan Wolfart Pannenberg bahwa istilah "Allah" ( $\theta \epsilon$ ò $)$ di dalam PB digunakan secara konsisten untuk merujuk kepada Bapa, jika tidak ada keterangan dari konteksnya mengenai rujukannya kepada pribadi yang lain. ${ }^{70}$ Karya Bapa ini dilakukan bersama dan di dalam Kristus dan akan mencapai kulminasinya (puncaknya) di masa depan (ay. 7). ${ }^{71}$ Bapa telah menghidupkan kita, di mana sebelumnya kita "mati karena dosa-dosa" (ay. 10. Pada gilirannya, Ia telah membangkitkan kita bersama dengan Kristus. Ini adalah tindakan yang berdaulat oleh Bapa. Selain itu, kita tidak dibangkitkan dalam ketersendirian. ${ }^{72}$ Kata kerja dalam ayat 5 dan ayat 6 secara konsisten memiliki awalan syn (yang berarti "dengan"). Kita dibawa kepada kehidupan dalam kaitan dengan yang lain, sebagai bagian dari tubuh korporat. Bahkan lebih lagi, kita diberi hidup dalam hubungan dan persatuan dengan Kristus, yang Bapa bangkitkan dari antara orang mati. Maka kita juga berbagian dalam kebangkitan-Nya. ${ }^{73}$ Jika kita mengingat komentar Paulus di Roma 8, Roh Kudus juga secara aktif terlibat dalam kebangkitan Kristus demikian juga dalam partisipasi kita di dalamnya - Bapa menggenapkannya melalui Roh Kudus. ${ }^{74}$

Bapa mendudukkan kita di atas takhta bersama dengan Kristus di sorga (ay. 6b). Inilah kelanjutan dan konsekuensi dari apa yang telah diulas di atas. Kristus naik ke sorga dan sekarang duduk di sebelah kanan Allah. Dalam persatuan dengan Dia, kita didudukkan bersama-sama dengan Dia (dan dalam Dia) di sorga. Maksudnya sekali lagi adalah bahwa Bapa terus menjadi subjek dari anak kalimat ini. Jadi, rencana keselamatan dalam keseluruhannya, demikian juga dalam detail-detailnya, adalah penggenapan kovenan Allah dengan Abraham, disiapkan dari sebelum penciptaan, difokuskan secara korporat dalam Kristus dan - di atas segalanya - adalah suatu janji dari Bapa, Anak, dan Roh Kudus yang memiliki satu tujuan, satu kehendak, dan satu pengaruh. ${ }^{75}$

67 Perlu dicatat bahwa dalam teks Yunaninya, Efesus 2:1-7 merupakan sebuah kalimat tunggal. Meski demikian, penulis membaginya sesuai pembagian di atas berdasarkan gagasan yang terkandung di dalamnya.

${ }^{68}$ Larkin, Ephesians: A Handbook on the Greek Text, 27.

${ }^{69}$ Lih. komentar detailnya dalam: Lincoln, Ephesians [Software version].

70 Wolfart Pannenberg, Systematic Theology, trans. Geoffrey W. Bromiley (Grand Rapids, Michigan: Eerdmans, 1991), 1.326.

71 Istilah "bersama” dan "di dalam" Kristus mengindikasikan bahwa Kristus adalah Agen keselamatan kita. Konsep "agen" di sini memiliki latar belakang Yahudi di mana seorang agen memiliki otoritas dan dapat bertindak sebagai representasi dari pengutusnya. Lih. Kitchen, Ephesians, 59-60.

72 Martin, Ephesians, Colossians, Philemon, 20.

73 Kitchen, Ephesians, 60.

${ }^{74}$ Lincoln, Ephesians [Software version].

75 Pannenberg, Systematic Theology, 1.327. 
Kedua, penerimaan keselamatan oleh anugerah semata (ay. 8-10). Penekanan akan anugerah atau kasih karunia dalam bagian ini konsisten dengan kondisi manusia sebelum mengalami karya penebusan Kristus. Kondisi kematian akibat dosa tidak mungkin menyisakan kemampuan atau potensi di dalam diri manusia itu sendiri yang memberinya peluang untuk menyelamatkan dirinya sendiri atas potensi dirinya. Selain itu, seperti yang sudah diuraikan dalam eskegesis terhadap Efesus 1:3-14 bahwa keselamatan itu diinisiasi, diwujudkan, dan digenapi oleh Bapa, Anak, dan Roh Kudus. Itu berarti, implikasi yang tidak dapat tidak harus diterima adalah bahwa keselamatan itu hanya dapat dinikmati oleh manusia karena anugerah atau kasih karunia semata dan bukan merupakan buah dari upaya atau usaha dari pihak manusia itu sendiri. ${ }^{76}$ Lincoln mengomentari ayat-ayat ini demikian: "Tindakan Allah yang beranugerah itu adalah fondasi dari keselamatan manusia yang diterima melalui iman sebagai sarana yang melaluinya tindakan tersebut menjadi efektif dalam kehidupan seseorang."77 Sebelumnya, Lincoln sudah memberikan argumentasi bahwa iman itu sendiri tidak bersumber dari dalam diri manusia melainkan harus dilihat juga sebagai pemberian Allah. ${ }^{78}$ Maka tidak heran, Ferguson pun menegaskan hal ini dengan berkomentar:

Kejeniusan rencana keselamatan Allah adalah bahwa Ia telah menciptakan sarana yaitu iman yang melaluinya kita dapat menikmati keselamatan, namun pada saat yang sama iman itu sendiri tidak berkontribusi bagi keselamatan kita. Keselamatan adalah pemberian cuma-cuma di mana iman tidak menambahkan apa pun kepadanya. Keselamatan, seluruhnya dan selalu merupakan anugerah. Itu tidak pernah bersumber dari natur manusia itu sendiri; itu tidak bergantung atas perbuatan manusia. Itu datangnya dari Allah; karena itu tidak ada seorang pun yang dapat membanggakan diri mengenai hal itu! Sesungguhnya ini adalah sebuah kejeniusan ilahi. $^{79}$

Jadi, Efesus 2:4-10 juga berbicara mengenai rencana keselamatan Allah bagi manusia di mana dasarnya adalah karya Bapa bersama dan di dalam Kristus yang membangkitkan serta menghidupkan kita dari kematian serta ketidakberdayaan akibat dosa. Itulah sebabnya, keselamatan itu ditekankan sebagai sebuah pemberian cuma-cuma; bukan merupakan hasil perbuatan atau jasa dari pihak manusia itu sendiri. Sedikit berbeda dengan Efesus 1:3-14 yang berbicara mengenai peran Bapa, Anak dan Roh Kudus, di dalam teks ini yang dibicarakan adalah peran Bapa dan Kristus bagi keselamatan manusia. ${ }^{80}$

\section{b. Pola Triadik dan Kehidupan Iman Umat Allah}

Mengenai pola triadik dan kehidupan iman umat Allah, dalam bagian ini saya akan membahas lima teks, yaitu: Efesus 1:17; 2:18; 3:4-17a; 5:18-20; dan 6:10-11.

\section{Efesus 1:17}

Efesus 1:17 berada dalam konteks lontaran Paulus mengenai doanya bagi jemaat untuk memiliki pengertian atau pengenalan akan kemuliaan Kristus (1:15-23). Di dalam 1:17, Paulus menggunakan pola triadik untuk berbicara mengenai sumber atau fondasi dari pengenalan akan Allah.

${ }^{76}$ Lih. Ferguson, Let's Study Ephesians, 50-51.

77 Lincoln, Ephesians [Software version].

${ }^{78}$ Lincoln, Ephesians [Software version].

79 Ferguson, Let's Study Ephesians, 52-53.

80 Klyne Snodgrass, Ephesians (The NIV Application Commenary of the NT; Grand Rapids, Michigan: Zondervan, 1996), 83. 


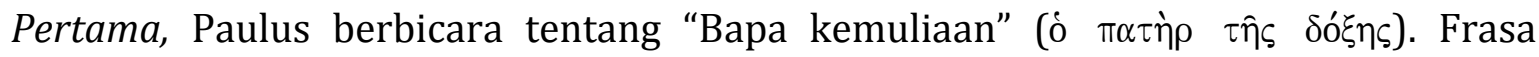
Yunani ini diterjemahkan dalam dua versi, yaitu "Bapa yang mulia" (the glorious Father ITB; BIS; NIV; NIB) dan "Bapa kemuliaan" (the Father of glory - KJV; NRS; ESV; GNV; dll.). Bila diterjemahkan dengan "Bapa yang mulia," maka maksudnya merujuk kepada kemuliaan sebagai modus keberadaan Bapa di mana penekannya pada kata sifat dari "kemuliaan". Namun, bila diterjemahkan dengan "Bapa kemuliaan", maka penekannya ada pada tindakan Allah di dalam sejarah di mana kemuliaan Allah selalu dihubungkan dengan tindakan-Nya dalam penyingkapan Diri-Nya. Misalnya dalam Keluaran 33:17 - 34:7 di mana Musa meminta agar melihat kemuliaan Allah (bnd. Kis. 7:2). ${ }^{81}$ Klyne Snodgrass menyatakan bahwa menurut konteksnya, frasa "Bapa kemuliaan" di sini harus dipahami dalam pengertian Bapa yang menyatakan kemuliaan-Nya yakni menyingkapkan diri, karakter, dan rencana-Nya untuk diketahui melalui Kristus. ${ }^{82}$ Atau seperti yang dikemukakan Harold Hoehner, bentuk genitif dari kata "kemuliaan" di sini adalah genitif kualitatif di mana Bapa dikarakterisasi oleh kemuliaan-Nya. Dia bukan hanya Bapa yang mulia, melainkan juga Bapa yang memiliki segala kemuliaan dan kemuliaan merupakan natur-Nya. ${ }^{83}$ Dan jangan lupa bahwa penyebutan mengenai "Bapa kemuliaan" di sini pasti merupakan bentuk ringkas dari karya Bapa yang sudah dibicarakan dalam Efesus 1:3-6 yang menginisasi keselamatan bagi umat-Nya. ${ }^{84}$

Kedua, Paulus berbicara mengenai Tuhan Yesus Kristus. Menariknya, frasa yang digunakan Paulus untuk berbicara mengenai Kristus adalah ò $\theta$ єò

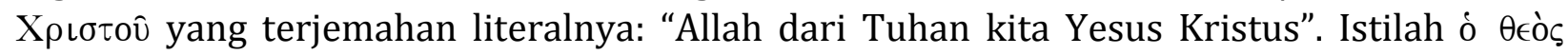

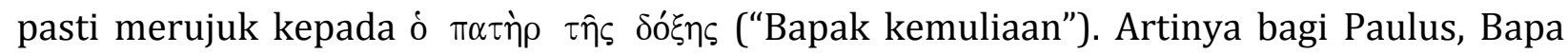
adalah Allah dari Tuhan Yesus Kristus, menurut ayat ini. Kelihatannya di sini Paulus membicarakan Kristus dalam posisi yang lebih rendah (subordinan) dari Bapa. ${ }^{85}$ Meski demikian, Gordon D. Fee memberikan argumentasi eksegetis yang kuat bahwa bukan ini

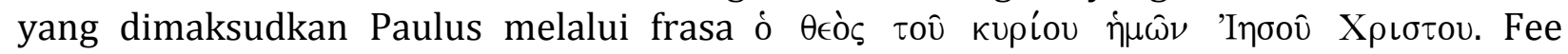
menyatakan bahwa: (a) Paulus dalam ayat ini mempresuposisikan Efesus 1:3dst., di mana Kristus dipresentasikan sebagai Pribadi yang pre-eksisten; (b) dalam ayat ini, Paulus bukan berbicara mengenai relasi Kristus dengan Bapa, melainkan relasi Bapa dengan Kristus di mana melalui Kristus, Bapa menyingkapkan diri dan kehendak-Nya; dan (c) dalam konteks 1:15-23, Paulus berbicara mengenai Allah sebagai Pribadi yang disembah oleh jemaat,

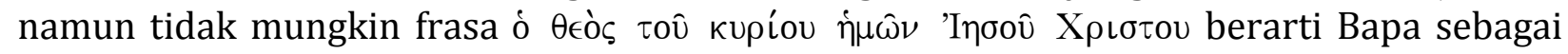
Pribadi yang disembah Kristus karena gagasan seperti ini secara total sama sekali tidak pernah muncul dalam teologi Paulus. ${ }^{86}$

Dan ketiga, Paulus berbicara mengenai Roh Kudus. Dalam bahasa Yunaninya, kata yang digunakan adalah $\pi \nu \in \hat{\nu} \mu \alpha$ ooфí $\alpha \varsigma$ tanpa kata sandang tertentu yang secara literal dapat diterjemahkan dengan "roh hikmat". Pertanyaannya adalah bagaimana kita bisa yakin bahwa istilah $\pi \nu \in \hat{v} \mu \alpha$ бoфí $\alpha \varsigma$ dimaksudkan untuk merujuk kepada Roh Kudus? Ada enam pokok pertimbangan eksegetis yang dikemukakan Hendrikson untuk meyakinkan kita bahwa Roh Kuduslah yang dimaksudkan di sini, yaitu:

a. Paulus menulis mengenai "pewahyuan" dalam hubungan dengan "roh hikmat". Kita tidak mungkin berbicara mengenai pewahyuan dalam hubungan dengan roh yang merujuk kepada kualitas diri manusia;

${ }^{81}$ Lincoln, Ephesians [Software version].

82 Snodgrass, Ephesians, 72.

83 Harold Hoehner, Ephesians: An Exegetical Commentary (Grand Rapids, Michigan: Baker, 2002), 255.

${ }^{84}$ Lih. Hendrikson, Galatians and Ephesians, 96.

85 Demikian tafsiran dari: Lincoln, Ephesians [Software version].

86 Gordon D. Fee, Pauline Christology: An Exegetical-Theological Study (Peabody, MA.: Hendrickson, 2007), 354. 
b. Paulus menggunakan istilah "roh hikmat" di mana menurut Yesaya 11:2 bahwa hikmat merupakan pemberian dari Roh Yahweh;

c. Dalam bagian-bagian lain, terdapat sejumlah frasa yang mirip dengan "roh hikmat" yang merujuk kepada Roh Kudus, mis. "Roh kebenaran" (Yoh. 15:26) dan "Roh adopsi" (Rm. 8:5);

d. Dalam Efesus 1:3-14, Bapa dan Anak dibicarakan bersama dengan Roh Kudus (pola triadik), maka dalam 1:17, pasti pola yang sama juga yang dimaksudkan Paulus;

e. Merupakan suatu karakteristik dalam tulisan Paulus untuk menyebut Bapa dan Anak kemudian juga Roh Kudus (mis. Rm. 8:15-17; 2Kor. 13:14; Ef. 1:3-14; 3:14-17; 4:4-6; 5:18-21); dan

f. Ketika Bapa memberikan mata hati yang terang (ay. 18), bukankah itu terjadi melalui Roh Kudus? (bnd. Yoh. 3:3, 5; Ef. 5:8; 1Yoh. 1:7).87

Pengenalan yang Bapa berikan bukan suatu pengetahuan hipotetis yang spekulatif. Paulus menggunakan epignosis untuk menunjukkan pengetahuan yang nyata, mendalam, pribadi, yang bertolak belakang dengan pengetahuan atau pengenalan sepintas lalu. Persekutuan pribadi dengan Allah menjadi maksud Paulus di sini. 88 Pengenalan akan Allah ini datang dari Bapa, melalui Anak, dan oleh Roh Kudus, dan berkesinambungan serta progresif. Terlebih lagi, pengenalan ini adalah hal yang paling penting dalam agenda Paulus bagi gereja. Ini adalah kategori yang teratas dalam daftar doanya, satu hal yang paling penting yang ia sebutkan. ${ }^{89}$

Jadi, di sini Paulus menggunakan pola triadik yaitu Bapa, Kristus, dan Roh Kudus di dalam konteks doanya di mana Ketiga Prbiadi tersebut akan memimpin orang-orang percaya ke dalam tiga hal, yaitu: pengenalan akan pengharapan yang ada pada panggilan mereka, pengenalan akan kekayaan dan kemuliaan dari status mereka sebagai orang-orang kudus, dan pengenalan akan kelimpahan yang agung dari Kristus bagi kita yang percaya kepada-Nya. ${ }^{90}$ Snodgrass menyatakan bahwa teks ini bersifat Teosentris sekaligus Trinitarian. ${ }^{91}$ Dengan kata lain, Bapa, Anak, dan Roh Kudus merupakan sumber sekaligus fondasi pengenalan akan Allah yang benar!

\section{Efesus 2:18}

Konteks dari Efesus 2:18 adalah penjelasan Paulus bahwa sekat-sekat etnis yang memisahkan orang-orang Yahudi dan non Yahudi kini telah ditiadakan di dalam Kristus. Karya Kristus meniadakan sekat-sekat tersebut dan membuka akses yang sama baik bagi orang-orang Yahudi maupun non Yahudi untuk beroleh jalan kepada Bapa (2:11-17). ${ }^{92}$ Latar belakang dari konteks ini adalah sistem penyembahan di Bait Suci sebagaimana yang diatur dalam PL. Menurut PL, ada jarak antara Allah dan umat-Nya. Hal ini terlihat dalam aturan mengenai Ruang Mahakudus yang tidak bisa diakses oleh semua orang. Terlebih lagi, orang-orang non Yahudi tidak diperkenankan untuk memasuki Bait Allah dan pelanggaran terhadap aturan ini akan menuai ganjaran hukuman mati. ${ }^{93}$ Melalui teks ini, Paulus secara implisit menyatakan bahwa baik orang-orang Yahudi maupun orang-orang

87 Hendrikson, Galatians and Ephesians, 37; bnd. Max Turner, "Ephesians,” in G.J. Wenham, et al (eds), New Bible Commentary (21 st-Century Edition; Downers Grove, Illinois: IVP Academic, 2007), 1227-1228.

88 Fee, Pauline Christology: An Exegetical-Theological Study, 355.

89 Fee, Pauline Christology: An Exegetical-Theological Study, 355.

90 Kitchen, Ephesians, 54.

91 Snodgrass, Ephesians, 73.

92 Lih. Fee, Pauline Christology: An Exegetical-Theological Study, 348.

93 Snodgrass, Ephesians, 126-127. 
non Yahudi sama tidak berdayanya di hadapan Allah. Keselamatan mereka sama-sama bergantung atas karya penebusan Kristus. ${ }^{94}$

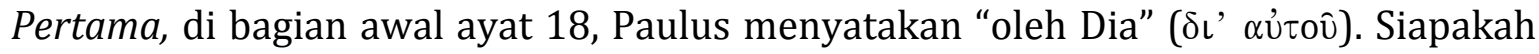
yang dimaksudkan "Dia" di sini? Jelas bahwa berdasarkan ayat 11-17, "Dia" yang dimaksudkan dalam awal ayat 18 adalah Kristus.

Kedua, Paulus menyatakan "dalam satu Roh" ('€v évì $\pi \nu \in \dot{\mu} \mu \alpha \tau \iota)$ kita beroleh akses

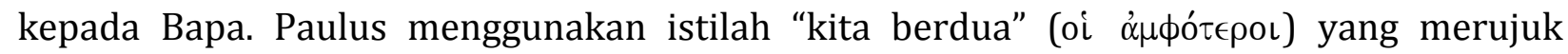
kepada orang-orang Yahudi dan orang-orang non Yahudi.

Dalam ayat ini Paulus menekankan bahwa Kristus telah menjamin akses kepada Allah melalui Salib. Dalam Perjanjian Lama, ada satu jarak antara Allah dan umat-Nya. Keimaman dan sistem persembahan korban ada di antara Allah dan umat-Nya. Ruang Mahakudus tidak bisa diakses oleh semua orang. Terlebih lagi, orang-orang bukan Yahudi tidak diijinkan memasuki Bait Allah, dan pelanggaran terhadap hal ini diganjar hukuman mati. Akan tetapi, sekarang karena Kristus telah datang, kita memiliki akses yang terbuka kepada Allah. Kita didamaikan melalui salib. Pendamaian ini juga memiliki pengaruh antara orang Yahudi dan bukan Yahudi. ${ }^{95}$

Martin menyatakan bahwa Kristus telah membatalkan hukum Taurat dan dengan demikian menghancurkan apa yang membedakan Israel dan memisahkan orang Yahudi dan bukan Yahudi. ${ }^{96}$ Ini adalah latar belakang bagi kalimat kunci dalam ayat 18. Baik orang-orang Yahudi maupun orang-orang bukan Yahudi sekarang memiliki akses kepada Bapa. Rahmat bapa yang kaya telah membebaskan kita dari dosa, membangkitkan kita dengan Kristus, dan mendamaikan kita melalui kematian Kristus. ${ }^{97}$ Karena itu keselamatan dapat dilihat sebagai akses kepada, dan, secara konsekuensi, persekutuan dengan Bapa. Akses ini terjadi "melalui Dia", melalui Kristus. Dialah yang mendamaikan dan yang adalah

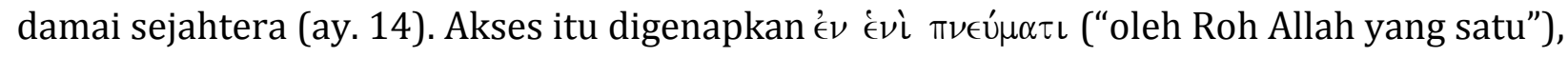
yang tidak lain merujuk kepada Roh Kudus. ${ }^{98}$

Akibatnya, meskipun rencana keselmatan diadakan dari Bapa melalui Anak oleh Roh Kudus, dari pihak kita sendiri, kita mengalami gerakan yang terbalik yaitu oleh Roh Kudus melalui Anak kepada Bapa. ${ }^{99}$ Roh memberi iman (bnd. 2:8-9) dan adalah sumber dari semua cara kita merespons anugerah Allah. Ia memampukan kita untuk mempercayai Kristus, dan melalui Dia dan perantaraan-Nya kita memiliki persekutuan dengan Bapa. Karena itu, pengalaman Kristen adalah benar-benar Trinitarian. ${ }^{100}$ Lincoln mengakui hal ini ketika ia berkomentar tentang surat Efesus, "Betapa wajarnya pemikirannya diungkapkan dalam pola Trinitarian 'melalui Kristus dalam Roh kepada Bapa'."101 Sesungguhnya itu adalah natur dari kalimat ini yang muncul tanpa disengaja yang menekankan bahwa pola ini adalah bagian integral dari pemikiran Paulus. Sayangnya, Herman Ridderbos tidak satu kalipun menyinggung mengenai hal ini dalam bukunya yang terkenal mengenai teologi Paulus. ${ }^{102}$

Jadi, melalui karya Roh Kudus, baik orang Yahudi maupun orang-orang non Yahudi memperoleh akses yang sama kepada Bapa. Jadi, bagi Paulus Roh Kudus mengefektifkan karya Kristus bagi orang-orang non Yahudi dan orang-orang Yahudi untuk menikmati jalan

\footnotetext{
${ }^{94}$ Lih. Heil, Ephesians: Empowerment to Walk in Love for the Unity of All in Christ, 131-132.

95 Fee, Pauline Christology: An Exegetical-Theological Study, 351.

96 Martin, Ephesians, Colossians, Philemon, 31.

97 Fee, Pauline Christology: An Exegetical-Theological Study, 351.

98 Hoehner, Ephesians: An Exegetical Commentary, 262.

99 Snodgrass, Ephesians, 134.

100 Snodgrass, Ephesians, 135.

101 Lincoln, Ephesians [Software version].

102 Herman Ridderbos, Paulus: Pemikiran Utama Theologinya, terj. Hendry Ongkowidjojo (Surabaya:
} Momentum, 2008). 
atau akses menuju kepada Bapa. Tanpa karya Kristus dan karya Roh Kudus, akses kepada Bapa sama sekali tertutup. Penerimaan Bapa dan pengenalan akan Dia, hanya dapat terjadi karena pengorbanan Kristus dan pengefektifan karya-Nya oleh Roh Kudus bagi setiap orang yang percaya. ${ }^{103}$ Implikasinya, mereka harus mengetahui bahwa kesatuan iman yang terjadi dalam relasi Yahudi-non Yahudi merupakan karya Bapa, Anak, dan Roh Kudus. ${ }^{104}$

\section{Efesus 3:4-17a}

Sama seperti dua teks di atas, dalam Efesus 3:4-17, Paulus juga berbicara mengenai pengetahuan akan Kristus. Namun dalam teks ini, Paulus lebih condong untuk berbicara mengenai pengetahuannya akan rahasia Kristus. Martin menyatakan bahwa teks ini merupakan autobiografi bagi apostolisitas (kerasulan) Paulus sendiri.105 Dan rahasia Kristus itu adalah bahwa orang-orang bukan Yahudi boleh berbagian sebagai ahli-hali waris dan anggota-anggota tubuh Kristus. Pengetahuan akan rahasia Kristus ini, menurut Paulus, "dinyatakan di dalam Roh". Jadi, kembali lagi Paulus membicarakan tentang karya Kristus yang dinyatakan atau yang disingkapkan oleh Roh Kudus. Roh Kudus adalah Penyingkap rahasia Allah. Atau dengan kata lain, Roh Kudus adalah pemberi iluminasi bagi Paulus untuk memahami rahasia Kristus yang sebenarnya sudah dicanangkan sejak masa para nabi (ay. 5).106 Pertanyaannya adalah mengapa Paulus berbicara mengenai posisi orang-orang non Yahudi sebagai sebuah rahasia yang kini telah disingkapkan?

Pertama, Paulus memberikan penekanan yang sangat kuat dalam teks ini bahwa baik orang Yahudi maupun orang-orang non Yahudi di dalam Kristus merupakan satu umat. Fee menjelaskan bahwa terjemahan bahasa Inggris (dan juga Indonesia?) kurang dapat mengekspresikan penekanan yang kuat ini sebagaimana yang dapat dirasakan saat membaca kalimat-kalimat Yunaninya. ${ }^{107}$ Kedua, maka Paulus menempatkan tugas kerasulannya dalam konteks rekonsiliasi antara Allah dengan orang-orang non Yahudi dan rekonsiliasi antara orang-orang non Yahudi dan orang-orang Yahudi. Konteksnya dengan jelas memperlihatkan bahwa Allah adalah Bapa bagi umat-Nya dan umat-Nya yang dimaksudkan di sini adalah semua orang dari segala suku bangsa. ${ }^{108}$ Ketiga, pelayanannya sebagai rasul bagi orang-orang non Yahudi merupakan mandat Allah sendiri (bnd. Gal. 1:11-12). Dan keempat, ia mendapatkan pengetahuan seperti ini berdasarkan penyingkapan dari Roh Kudus. ${ }^{109}$

Menarik untuk dicatat bahwa dalam Efesus 1:9, Paulus berbicara mengenai karya pengorbanan Kristus sebagai penyingkapan rahasia Allah (Bapa) dan dalam bagian ini, ia membicarakan topik yang sama dalam kaitan dengan rekonsiliasi Yahudi-non Yahudi sebagai "rahasia Kristus". Bagi Paulus, istilah "rahasia Allah" dan "rahasia Kristus" digunakan secara bergantian untuk berbicara mengenai karya penebusan Kristus sebagai puncak atau klimaks dari pewahyuan Allah di dalam PL. ${ }^{110}$ Rahasia ini menjadi tersingkap melalui karya Roh Kudus. ${ }^{111}$

Jadi, teks ini bisa dilihat sebagai sebuah doa lain bagi para pembaca yang didasarkan pada isi bagian sebelumnya. Paulus memohon kepada Bapa untuk menguatkan para pembacanya melalui Roh-Nya (ay. 15-16). Pada gilirannya ia menggambarkan hal ini

\footnotetext{
103 Fee, Pauline Christology: An Exegetical-Theological Study, 348.

104 Heil, Ephesians: Empowerment to Walk in Love for the Unity of All in Christ, 132.

105 Martin, Ephesians, Colossians, Philemon, 40.

106 Lincoln, Ephesians [Software version].

107 Fee, Pauline Christology: An Exegetical-Theological Study, 348.

108 Fee, Pauline Christology: An Exegetical-Theological Study, 349.

${ }^{109}$ Lincoln, Ephesians [Software version].

110 Lih. W. Harold Mare, "Paul's Mystery in Ephesians 3," in Bulletin of the Evangelical Theological

111 Lih. Ridderbos, Paulus: Pemikiran Utama Theologinya, 187-211.
} Society 8.2 (1980): 77-84. 
sebagai Kristus yang berdiam di dalam hati umat-Nya melalui iman (ay. 17). Bapa, menurut Paulus adalah "kaya dalam kemuliaan".112 Penekanannya ada pada kebesaran Bapa sebagai sumber berkat ini. Ia adalah Pencipta dan Tuhan dari semua turunan. Turunan-turunan itu berasal dari Dia. Memberi nama memperlihatkan gagasan kedaulatan dalam dunia purba, maka yang dimaksudkan di sini adalah otoritas yang berdaulat dari Bapa atas semua orang. Roh Kudus sudah digambarkan sebagai materai dari keselamatan kita (1:13) dan Dia yang mendiami gereja (2:22). Di sini kuasa Roh Kudus yang menguatkan sejajar dengan berdiamnya Kristus dalam hati orang beriman. Hasilnya adalah mereka akan berakar dalam kasih dengan akibat lebih lanjut yang Paulus uraikan dalam kalimat-kalimat selanjutnya. Iman, penguatan, dan kasih - semua ciri kehidupan orang-orang percaya Kristen - dilihat oleh Paulus sebagai buah janji bersama dari ketiga Pribadi. ${ }^{113}$

\section{Efesus 5:18-21}

Pola triadik yang berikutnya terungkap dalam tulisan Paulus mengenai "dipenuhi oleh Roh" (5:18-20). Latar belakang gagasan teologis ${ }^{114}$ dari teks ini dapat dilihat dalam PL di mana berulang kali dicatat bahwa Roh Allah memenuhi orang-orang tertentu, mis. untuk misi profetis (Yeh. 2:2; 3:4) dan menyampaikan nubuat tertentu (1Sam. 10:6, 10; 19:23; Mi. 3:8). Roh, dalam PL, juga dinyatakan memenuhi orang-orang tertentu dengan memberikan keahlian-keahlian khusus bagi mereka untuk menyelesaikan sejumlah tugas dari Allah (Kel. 28:3; 31:3-5; 35:31; Ul. 34:9; Hak. 3:10; 6:34; 11:29; 14:19; 1Sam. 16:13; 2Taw. 15:1; 20:14). ${ }^{115}$ Andreas J. Kostenberger memperlihatkan bahwa dalam PL, istilah "dipenuh" oleh Roh merujuk kepada beberapa konsep, yaitu:
a. Berasosiasi dengan terminologi Tabernakel/Bait Suci di mana beberapa kali dinyatakan bahwa Roh Allah memenuhi Tabernakel atau Bait Suci dengan kemuliaan Allah (Kel. 40:34-35; 1Raj. 8:10-11; 2Taw. 5:13-14; 7:1-2; Hag. 2:7; Yeh. 10:4; 43:5; 44:4; Im. 14:21; Mzm. 72:19; Yes. 6:3; 11:9; Hab. 2:14);
b. Memiliki dimensi eskatologis (Mzm. 72:19; Yes. 6:3; Yeh. 36:26-27);
c. Memiliki dimensi koorporat (Yeh. 36:6, 14; Yes. 63:10-11); dan
d. Memiliki dimensi individual (lih. referensi yang sudah dicantumkan sebelumnya). ${ }^{116}$

Dalam Efesus 5:18-20, hanya ada satu kata kerja utama dalam kaitan dengan Roh Kudus, yaitu kata $\pi \lambda \eta \rho \circ \hat{\sigma} \sigma \epsilon \in$ (present imperatif pasif, orang kedua jamak dari kata $\pi \lambda \eta \rho o ́ \omega) .{ }^{117}$ Kata kerja utama ini kemudian diikuti dengan lima kata partisip, yaitu:
a. Berkata-kata dengan Mazmur, kidung pujian, dan nyanyian rohani (ay. 19);
b. Bernyanyi dan bersorak bagi Tuhan (ay. 19);
c. Mengucap syukur senantiasa (ay. 20);
d. Dan merendahkan diri seorang terhadap yang lain (ay. 21).

112 Mare, "Paul's Mystery in Ephesians 3," 83.

113 Mare, "Paul's Mystery in Ephesians 3," 84.

114 Sementara itu, latar belakang historis dari teks ini kemungkinan berhubungan dengan konteks makan bersama dalam perjamuan malam, seperti yang ditunjukkan dalam: Peter W. Gosnell, "Ephesians 5:1820 and Mealtime Propierty," in Tyndale Bulletin 44.2 (1993): 363-371.

115 Bnd. L. J. Wood, The Holy Spirit in the Old Testament (Grand Rapids: Zondervan, 1976), 39-52.

116 Andreas J. Kostenberger, "What Does It Mean to be Filled with the Spirit? A Biblical Investigation," in Journal of Evangelical Theological Society 40.2 (June 1997): 230-231.

117 Ini adalah satu-satunya teks di mana Paulus berbicara mengenai dipenuhi dengan Roh Kudus. Dalam teks-teks lainya, Paulus menggunakan frasa yang berbeda. Lih. K. H. Easley, "The Pauline Usage of Pneumati as a Reference to the Spirit of God," in Journal of Evangelical Theological Society 27 (1984): 299313. 
Karena kelima kata di atas ditulis dalam bentuk partisip, maka fungsinya dalam Efesus 5:18-20 adalah sebagai penjelasan bagi apa yang dimaksud dengan "dipenuhi dengan Roh kudus". Dengan kata lain, dipenuhi dengan Roh kudus terlihat dalam kelima karakterstik yang terungkap di atas. ${ }^{118}$

Ada beberapa pokok penting yang perlu dicatat di sini berkait dengan perintah untuk dipenuhi dengan Roh Kudus. Pertama, bentuk tense dari kata "dipenuhi" adalah present tense, sehingga banyak penafsir yang menganggapnya mengindikasikan suatu tindakan yang terus-menerus. ${ }^{119}$ Tafsiran ini didukung oleh konteksnya di mana kelima karakteristik dari dipenuhi oleh Roh Kudus di atas merupakan hal-hal yang harus terus menerus dilakukan oleh umat Tuhan. Artinya, dipenuhi dengan Roh Kudus berbeda dengan dimateraikan atau dibaptis dengan Roh Kudus yang dibicarakan dalam Efesus 1:14. Dipenuhi dengan Roh Kudus adalah sesuatu yang terus-menerus, sedangkan dimateraikan atau dibaptis dengan Roh Kudus adalah tindakan Allah yang satu kali untuk selamanya. Paulus memberikan perintah untuk dipenuhi dengan Roh Kudus, namun ia tidak pernah memberikan perintah untuk dibaptis atau dimateraikan dengan Roh Kudus. ${ }^{120}$

Kedua, ada suatu paradoks di sini, yaitu bahwa Paulus menggunakan kata perintah, namun kata perintah itu digunakan dalam modus pasif. Menurut Kostenberger, bentuk pasif ini mengindikasikan apa yang disebut dengan bentuk "pasif ilahi" (divine passive), yaitu suatu cara pengungkapan khas Yahudi di mana tindakan Allah dibicarakan dengan menggunakan bentuk pasif tanpa penyebutan nama Allah di sina. ${ }^{121}$ Artinya, dipenuhi oleh Roh Kudus bukan hanya melibatkan aktivitas manusia, melainkan juga karya Allah. ${ }^{122}$

Ketiga, teks ini ditulis dalam konteks komunitas, bukan semata-mata individual. Jadi, dipenuhi dengan Roh Kudus di sini terkarakterisasi dalam cara hidup komunitas iman, yaitu jemaat Kristus. Artinya, penekanan akan dipenuhi dengan Roh Kudus di sini dilakukan Paulus dalam konteks jemaat, bukan sekadar pengalaman individual dari orangorang percaya. ${ }^{123}$

Keempat, Roh Kudus memenuhi umat percaya dalam nama Tuhan Yesus ${ }^{124}$ supaya orang-orang percaya memuliakan Bapa (ay. 20). Dan kelima, dalam ayat-ayat sebelumnya "mabuk oleh anggur" diparalelkan dengan "kebodohan", sedangkan "dipenuhi dengan Roh Kudus" diparalelkan dengan "hidup yang berhikmat". Maka, sekali lagi dipenuhi dengan Roh Kudus di sini menegaskan peran Roh Kudus sebagai Roh Hikmat yang sudah dibicarakan dalam 1:17. Artinya, Roh Kudus memenuhi orang percaya dengan memberikan mereka iluminasi, hikmat, dan pengetahuan untuk mengekspresikan pemujaan terhadap Allah di dalam iman kepada Kristus dengan berbagai macam cara seperti yang sudah disebutkan di atas. ${ }^{125}$

Jadi, melalui teks ini kita kembali mendapati gagasan bahwa spiritualitas Kristen yang dipenuhi oleh Roh Kudus pun dikemas dalam kerangka atau pola triadik. ${ }^{126}$ Di sini menjadi sangat penting untuk diperhatikan bahwa permintaan Paulus kepada gereja untuk dipenuhi dengan Roh Kudus (ay. 18) mengantisipasi respons yang tidak terpisahkan

118 Lih. Thomas R. Schreiner, Paul the Apostle of God's Glory in Christ: A Pauline Theology (Downers Grove, Illinois/Leicester: IVP/Apolos, 2001), 422.

${ }^{119}$ Lih. Heil, Ephesians: Empowerment to Walk in Love for the Unity of All in Christ, 235.

120 Martin, Ephesians, Colossians, Philemon, 67.

${ }^{121}$ Kostenberger, "What Does It Mean to be Filled with the Spirit? A Biblical Investigation," 232.

122 Kostenberger, "What Does It Mean to be Filled with the Spirit? A Biblical Investigation," 233.

123 Kostenberger, "What Does It Mean to be Filled with the Spirit? A Biblical Investigation," 234.

124 Dalam teks Yunaninya, tidak disebutkan "Tuhan Yesus," melainkan "dalam nama Tuhan”. Meski demikian, semua penafsir sepakat bahwa istilah kyrios di sini dimaksudkan untuk Yesus. Lih. Heil, Ephesians: Empowerment to Walk in Love for the Unity of All in Christ, 238.

125 Kostenberger, "What Does It Mean to be Filled with the Spirit? A Biblical Investigation," 232.

126 Lih. Timothy B. Gombis, "Being the Fullness of God in Christ by the Spirit: Ephesians 5:18 in Its Epistolary Setting," in Tyndale Bulletin 53.2 (2002): 259-271. 
berupa nyanyian Mazmur kepada Tuhan (ay. 19), kyrios adalah istilah yang Paulus gunakan secara konsisten untuk Kristus pasca-kebangkitan. ${ }^{127}$ Pada gilirannya, mereka bersyukur untuk segala sesuatu yang mereka terima "dalam nama Tuhan kita Yesus Kristus kepada Allah dan Bapa Kita" (ay. 20). ${ }^{128}$ Sekali lagi, Paulus melihat bahwa pengalaman Kristen seluruhnya bersifat Trinitarian. Peramuannya tidak mulus, tetapi ciri ini menunjukkan cara yang wajar dalam mengakui realitas itu dan juga menunjukkan bahwa penulisannya terjadi pada awal perkembangan gereja. ${ }^{129}$

\section{Efesus 6:10-11}

Bila digabungkan dengan ayat-ayat setelahnya, Efesus 6:10-24 merupakan bagian penutup dari surat Efesus. Menurut Larkin, bagian ini tampaknya tidak dimaksudkan sebagai kesimpulan dari paraenesis (nasihat-nasihat praktis) dalm bagian sebelumnya, melainkan harus dilihat sebagai kesimpulan dari keseluruhan surat ini. ${ }^{130}$ Ayat 10-11 merupakan perintah yang pertama dalam rangkaian perintah untuk mempersenjatai diri dengan perlengkapan-perlengkapan rohani. ${ }^{131}$ Dalam perintah yang pertama dan juga perintahperintah lainnya hingga ayat 16, Paulus menggunakan pengungkapan-pengungkapan dengan latar belakang militer. Snodgrass menjelaskan bahwa latar belakang bernada militer ini sangat umum dalam PL di mana Yahweh digambarkan sebagai Pahlawan perang yang berperang melawan musuh-musuh-Nya. Metafora perang ini terdapat paling banyak di dalam kitab Yesaya dan juga beberapa kita pseudopigrafa PL. ${ }^{132}$ Gambaran seperti ini juga sangat kentara di dalam tulisan-tulisan masyarakat Qumran yang dikenal dengan istilah War Scrolls (Gulungan-gulungan Perang). Memang tidak dapat dibuktikan bahwa Paulus bergantung atas tulisan-tulisan Qumran tersebut, namun dapat disimpulkan bahwa metafora seperti ini memang sangat umum dalam konteks Yudaisme. Perbedaannya adalah, dalam tulisan-tulisan Qumran, para imam memberikan dorongan semangat untuk terlibat dalam peperangan yang nyata, sedangkan Paulus memberikan dorongan agar orang-orang percaya terlibat dalam peperangan rohani. ${ }^{133}$

Di dalam teks ini (2:10-11), Paulus secara tersirat berbicara mengenai keterlibatan tiga Pribadi (pola triadik). Paulus menyebutkan mengenai "hendaklah kamu kuat di dalam Tuhan". Kata Yunani yang digunakan di sini adalah ku,rioj yang merupakan ungkapan khas

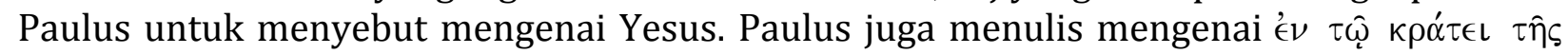

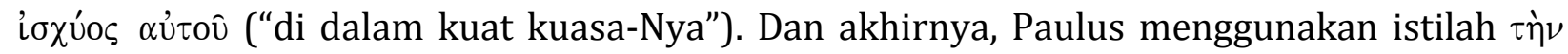

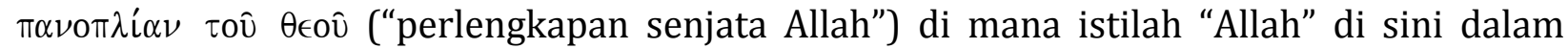
tulisan-tulisan Paulus digunakan untuk Bapa seperti yang sudah dijelaskan sebelumnya. Menariknya, dari semua "perlengkapan senjata Allah" yang dibicarakan Paulus dalam konteks ini, satu-satunya senjata yang memiliki fungsi menyerang adalah "pedang Roh", yaitu firman Allah (ay. 17). Jadi, Bapa melindungi umat-Nya supaya tetap teguh dalam iman kepada Kristus, dengan memberikan berbagai perlengkapan pertahanan maupun perlengkapan untuk mengalahkan iblis, yakni firman Allah yang merupakan karya Roh Kudus. ${ }^{134}$ Singkatnya, teks ini berbicara mengenai keterlibatan rangkap tiga, yaitu Bapa, Anak, dan Roh Kudus dalam menjaga iman umat-Nya. Umat-Nya diperintahkan untuk aktif, namun mereka tidak dibiarkan sendiri berjuang. Allah beserta dan menyertai bahkan

127 Gombis, "Being the Fullness of God in Christ by the Spirit: Ephesians 5:18 in Its Epistolary Setting," 260.

${ }^{128}$ Heil, Ephesians: Empowerment to Walk in Love for the Unity of All in Christ, 236.

${ }^{129}$ Schreiner, Paul the Apostle of God's Glory in Christ: A Pauline Theology, 423.

130 Larkin, Ephesians: A Handbook to the Greek Text, 155.

${ }^{131}$ Lih. Larkin, Ephesians: A Handbook to the Greek Text, 155.

132 Snodgrass, Ephesians, 336.

133 Snodgrass, Ephesians, 336.

${ }^{134}$ Hendrikson, Galatians and Ephesians, 270. 
menyediakan perlengkapan-perlengkapan yang diperlukan umat-Nya untuk tetap bertahan bahkan mengalahkan serangan si jahat. ${ }^{135}$

Sebagai ringkasannya, Paulus berbicara mengenai respons terhadap anugerah Allah, yang direncanakan dan dilaksanakan dalam pola rangkap tiga yang telah digambarkan di atas. Orang-orang percaya diangkat, diliputi, dan diberi kuasa oleh pola rangkap tiga yang sama - dalam teks ini: oleh Roh Kudus melalui Anak kepada Bapa. Hal ini bisa diperhatiakn dalam ayat 10: "Hendaklah kamu kuat di dalam Tuhan". Untuk melakukan hal ini, para pembacanya harus mengenakan seluruh perlengkapan senjata Allah (ay. 11). Satu-satunya perlengkapan untuk menyerang adalah "pedang Roh [Kudus], yang adalah firman Allah" (ay. 17). Dengan kata lain, kehidupan mereka dalam status sebagai umat Allah merupakan karya Trinitarian. ${ }^{136}$

\section{c. Pola Triadik dan Gereja/Jemaat}

Dalam bagian ini ada dua teks yang akan dibahas, yaitu Efesus 2:20-22 dan 4:4-6. Kedua teks ini berbicara mengenai pola triadik dan natur dari gereja/jemaat Tuhan.

\section{Efesus 2:20-22}

Di dalam konteksnya, Paulus berbicara mengenai rekonsiliasi antara orang-orang non Yahudi dan Yahudi dengan Allah karena karya salib Kristus. Kedua kelompok ini samasama mendapat kesempatan dan hak yang sama untuk beroleh akses kepada Bapa karena karya Kristus melalui pengefektifan yang dilakukan oleh Roh Kudus. Hasilnya, mereka tidak lagi dianggap sebagai "orang-orang asing" tetapi sebagai "kawan sewarga dan orangorang kudus dan anggota-anggota keluarga Allah" (2:11-19). ${ }^{137}$ Selanjutnya, Paulus kembali mempresentasikan pola triadik, yaitu bahwa dasar peletakkan atau fondasi pembentukkan umat Allah adalah pengajaran para rasul dan nabi di mana Kristus Yesus sebagai "batu penjuru" (ay. 20). Ferguson berkomentar bahwa penyebutan "para rasul dan para nabi" di sini tidak berarti bahwa mereka berkontribusi sebagai dasar pembangunan tubuh Kristus sebagaimana halnya Kristus. Sebaliknya, mereka adalah sarana-sarana yang digunakan Allah untuk menjadi duta Kristus guna meneruskan karya Kristus sehingga jemaat itu terbentuk dalam iman yang solid kepada Kristus. Perjanjian Baru secara konsisten mengajarkan bahwa hanya Kristuslah satu-satunya fondasi atau dasar bagi gereja (1Kor. 3:11) dan para pelayan-Nya adalah berperan sebagai duta atau agen. Tuhan memang memberikan para rasul peran kunci dalam pembangunan tubuh Kristus, namun mereka tidak memberikan kontribusi penebusan sebagaimana karya Kristus bagi jemaatNya (Mat. 28:18-20; Yoh. 20:21-23).138 Jemaat yang didirikan atas dasar Kristus ini bertumbuh dalam suatu harmonisasi spiritual menjadi "Bait Allah" dan "kediaman Allah" melalui karya Roh Kudus (ay. 21-22). ${ }^{139}$

Artinya dalam Efesus 2:20-22, Paulus berbicara mengenai gambaran tentang gereja sebagai Bait Suci, yang dibangun di atas dasar para rasul dan para nabi, dengan Kristus Yesus sebagai batu penjuru. Ada beberapa perdebatan mengenai apakah Paulus memandang Kristus sebagai batu penjuru, yang diletakkan sebelum semua bagian lain dari bangunan didirikan, atau sebaliknya apakah Ia memaksudkan batu puncak di mana Kristus akan menjadi bagian akhir dari bangunan itu, memasangnya dan menyelesaikannya. ${ }^{140}$ Gambaran itu tampaknya lebih mendukung sebelumnya, karena struktur bertumbuh ke

135 Hendrikson, Galatians and Ephesians, 271-272.

136 Larkin, Ephesians: A Handbook to the Greek Text, 155.

137 Ferguson, Let's Study Ephesians, 69-70.

138 Ferguson, Let's Study Ephesians, 70-71.

139 Teks ini memiliki kaitan erat dengan 1 Petrus 2:1-10, lih. Klyne Snodgrass, “1 Peter 2:1-10: Its Formation and Literary Affinities," in New Testament Studies 24 (1977): 97-106.

140 Hoehner, Ephesians: An Exegetical Commentary, 254. 
atas setelah dasar rasuli diletakkan pada tempatnya dan dengan demikian setelah Kristus mendirikannya. Jika Kristus adalah suatu puncak yang terakhir, itu berarti bangunan yang berkembang tersebut tidak memiliki Kristus untuk keseluruhan bangunannya, yang mana mungkin merupakan sebuah keganjilan yang jelas. ${ }^{141}$

Gambaran ini adalah mengenai pertumbuhan dan perkembangan yang selaras. Bangunan ini adalah bangunan yang hidup, terdiri atas orang banyak, bukan batu. Bangunan ini bertumbuh secara organis. ${ }^{142}$ Implikasinya adalah bahwa perkembangannya, seperti Bait Suci yang di Yerusalem - atau, kita mungkin bisa tambahkan, seperti pembangunan dari banyak katedral kuno - memerlukan proses yang lama. Itu adalah

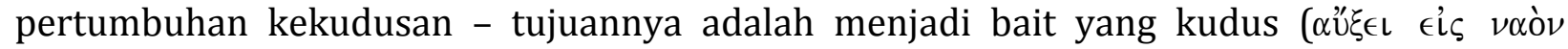

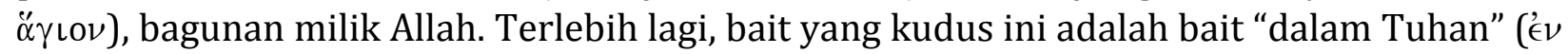
кupí( ). Identitas gereja ada dalam Kristus dan bukan identitas di luar Kristus bahkan dalam

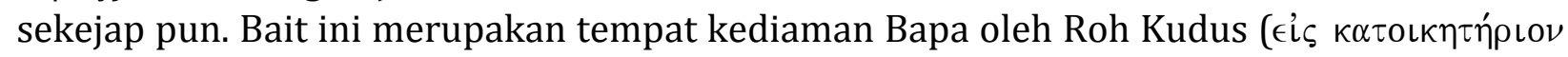

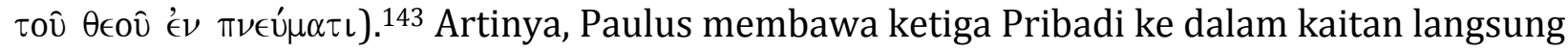
dengan gereja. Gereja sendiri menyatakan Trinitas, karena gereja ada dalam Kristus dan Bapa mendiami gereja melalui Roh Kudus. Jadi, eksistensi gereja dalam dunia merupakan terbentuk atas dasar karya Kristus, dipelihara dalam karya Roh Kudus, supaya menjadi umat hidup sebagaimana yang dikehendaki oleh Bapa. ${ }^{144}$

\section{Efesus 4:4-6}

Teks ini berbicara mengenai kesatuan jemaat. Dan perhatikan bahwa Paulus pada titik ini telah berpindah dari gereja sebagai bait yang bertumbuh, didiami oleh Roh Kudus, kepada kesatuannya. Kesatuan yang ditandai dengan sikap hidup yang baik, sebagaimana yang digambarkan dalam 4:1-3. Paulus menyebut kehidupan dalam kesatuan itu dengan sebutan "kesatuan Roh" (ay. 3). Artinya, Paulus sedang berbicara mengenai kehidupan gereja sebagai umat Allah yang bertumbuh dimana pertumbuhan itu harus ditandai dengan adanya kesatuan di antara mereka. Bisa jadi bahwa nasihat-nasihat praktis yang agak rinci dalam ayat 1-3 mengindikasikan adanya gejala ketidaksatuan dalam jemaat yang sedang ditangani oleh Paulus. ${ }^{145}$ Selanjutnya, Paulus memberikan alasan mengapa jemaat harus memelihara kesatuannya, yaitu karena jemaat itu memiliki "satu Roh", "satu Tuhan", dan "satu Allah dan Bapa". Sebutan-sebutan ini tidak dapat tidak merujuk kepada Bapa, Anak, dan Roh Kudus sebagaimana yang tersebar di seluruh surat ini. Artinya, peran Trinitarian ini menjadi fondasi dari paraenesis Paulus bagi jemaat agar memelihara kesatuan di dalam hubungan dengan sesama orang percaya. Bukan hanya itu, di dalam pengungkapannya pun, Paulus menggunakan struktur triadik untuk menasihati jemaat: (a) tubuh, Roh, pengharapan; (b) Tuhan, iman, baptisan; dan (c) satu Allah dan Bapa, yang di atas semuanya, oleh semuanya, dan di dalam semuanya. Itulah sebabnya, Snodgrass dengan tegas menyatakan, "Sekali lagi kita menemukan material yang berfokus Trinitarian dan Theo-logi [Theosentris]". ${ }^{146}$

${ }^{141}$ Hoehner, Ephesians: An Exegetical Commentary, 254-255.

142 Schreiner, Paul the Apostle of God's Glory in Christ: A Pauline Theology, 416.

${ }^{143}$ Heil, Ephesians: Empowerment to Walk in Love for the Unity of All in Christ, 225.

144 Schreiner, Paul the Apostle of God's Glory in Christ: A Pauline Theology, 417.

145 Dugaan seperti ini biasanya didapatkan dengan melakukan cara membaca terhadap surat-surat Paulus yang dikenal dengan sebutan mirror reading. Cara membaca seperti ini adalah cara mendeteksi sebuah situasi historis berdasarkan cerminannya dalam tulisan-tulisan eksplisit Paulus. Mengenai mirror reading, lih. Thomas R. Schreiner, "Interpreting Pauline Epistles," in David Alan Black and David S. Dockery (eds), Interpreting the New Testament: Essays on Methods and Issues (Nashville, Tennessee: Broadman \& Holman Publishers, 2001), 415-421.

146 Snodgrass, Ephesians, 198. 
Harus dicatat bahwa bagian ini memiliki bentuk himne atau kredo yang kuat. Ada "tujuh pujian bagi ke-satu-an [oneness]", seperti yang Lincoln nyatakan. Ketujuh pujian itu terbagi menjadi dua kelompok yang masing-masing terdiri atas tiga pujian, bersama dengan pernyataan penutup yang tersusun dalam bentuk rangkap tiga. ${ }^{147}$ Poin utama dari pengamatan ini memperlihatkan akan kebutuhan untuk memelihara kesatuan (unity) di Efesus. Ini adalah satu-satunya jalur yang konsisten dengan kesatuan-kesatuan dasar kesatuan gereja, kesatuan iman Kristen, dan kesatuan Allah sendiri. Gagasan ini akan diberi penjelasan detail berikut ini.

Dalam ayat 4, Paulus menyebut mengenai "satu tubuh" yang agaknya merupakan suatu referensi kepada Gereja, tubuh Kristus. Ini akan merupakan tema inti dari paragraph berikutnya dan tentu saja, adalah suatu poin yang diuraikan dengan panjang lebar oleh Paulus dalam suratnya yang pertama kepada jemaat di Korintus. "Satu Roh" jelas berarti Roh Kudus. "Satu pengharapan yang terkandung dalam panggilanmu" melihat kembali kepada Efesus 1:18, di mana Paulus berdoa agar jemaat di Efesus mengetahui apa pengharapan dari panggilan mereka itu dan di mana harapan tersebut menunjuk pada penggenapan akhir yang eskatologis dari rencana keselamatan Allah yakni kesatuan kosmis yang akan digenapi di dalam Kristus. Hal ini memiliki signifikansi tambahan jika, seperti yang terlihat dalam Efesus 2 bahwa terdapat percampuran antara orang Kristen Yahudi dan orang Kristen bukan Yahudi dalam gereja itu, karena keadaan ini akan menggarisbawahi bahwa apa pun perbedaan etnik yang ada, kesatuan yang Kristus dirikan dalam gereja-Nya pasti melampaui semua perbedaan itu. ${ }^{148}$

Dalam ayat 5, Paulus melontarkan mengenai "satu Tuhan" yaitu Yesus Kristus, Sang Anak yang adalah batu penjur dari gereja (2:20). "Satu iman" pada gilirannya menunjuk kepada kesatuan dari isi Injil Kristen, mungkin, seperti argument yang dikemukakan beberapa ahli, iman yang diakui oleh calon baptisan mengenai pertobatan mereka dari kekafiran. "Satu baptisan": hanya satu, karena di dalam baptisan kita disatukan dengan Kristus dalam kematian dan kebangkitan-Nya, dan sebagaimana hanya satu Kristus, dan hanya satu salib dan kebangkitan, baptisan dapat terjadi hanya sekali. ${ }^{149}$

Dalam ayat 6, Paulus menyatakan mengenai "Satu Allah dan Bapa dari semua." Allah Bapalah yang dimaksudkan di sini, dan Ia "di atas semua", melampaui seluruh ciptaan-Nya, imanensi-Nya. ${ }^{150}$ Gambaran rangkap tiga akan Bapa ini dalam kaitan dengan segala sesuatunya memang tidak dapat diambil begitu saja sebagai suatu rujukan kepada Trinitas itu sendiri. Meskipun demikian, aspek rangkap tiga ini hampir pasti merefleksikan pemahaman Paulus yang konsisten akan Allah dalam arti rangkap tiga. ${ }^{151}$

Jadi, dalam perikop ini, Paulus menekankan mengenai kesatuan Allah dengan mengambil pola rangkap tiga. Lebih dari itu, karena Tuhan dan Roh berbagian dengan Bapa dalam kualitas-kualitas Allah, Mereka sama-sama merupakan Pribadi. Pola rangkap tiga Paulus adalah pola yang menyatakan Pribadi yang pasti, meskipun ia tentu saja tidak menggunakan kata-kata itu, yang baru muncul kemudian seiring berjalannya waktu. Roh Kudus terlihat dalam ayat 4, Anak terlihat dalam ayat 5, dan Bapa terlihat dalam ayat 6. Dari hal ini mengalir kesatuan iman dan kesatuan gereja. Kita seharusnya memperhatikan bahwa ini adalah suatu kesatuan dalam keragaman. Mungkin pluralitas adalah kata yang lebih baik. Ketika ia melanjutkan untuk menjelaskannya, Paulus melihat kesatuan gereja terdiri dari keragaman orang-orang dengan beragam karunia (ay. 7-16). Ini sangat serasi

\footnotetext{
147 Lincoln, Ephesians [Software version].

148 Snodgrass, Ephesians, 199.

${ }^{149}$ Hoehner, Ephesians: An Exegetical Commentary, 262.

150 Hoehner, Ephesians: An Exegetical Commentary, 263.

151 Schreiner, Paul the Apostle of God's Glory in Christ: A Pauline Theology, 421.
} 
dengan pandangannya tentang Allah, yang bukan monad yang tersendiri, melainkan yang kesatuannya menunjukkan pola rangkap tiga dari aktivitas Pribadi. ${ }^{152}$

\section{d. Kesimpulan Eksegesis}

Di dalam teks-teks yang sudah dicermati serta diulas secara eksegetis di atas, kita mendapati bahwa semua aspek dari pembentukan spiritualitas jemaat: rencana Allah di dalam kekekalan, keselamatan di dalam Kristus, jaminan keselamatan di dalam Roh Kudus, pengenalan dan pengetahuan akan Allah, kehidupan iman yang bertumbuh yang dipenuhi Roh Kudus dan ditandai dengan kesatuan iman, serta daya tahan dan perlawanan terhadap serangan si jahat, semuanya dibahasakan Paulus dalam pengungkapan-pengungkapan Trinitarian yaitu dengan menggunakan pola-pola triadik: Bapa, Anak, dan Roh Kudus.

Yang perlu digarisbawahi di sini adalah bahwa Paulus dalam surat Efesus tidak membahas tentang relasi ontologis dari Bapa, Anak, dan Roh Kudus. Fokus Paulus adalah memperlihatkan kepada jemaat bahwa dari kekekalan, masa kini, dan masa mendatang di dalam kekekalan, kehidupan spiritual mereka merupakan hasil dari inisitatif, karya, perlindungan, penyertaan, dan pertolongan Bapa, Anak, dan Roh Kudus, yang dapat dinikmati sebagai sebuah anugerah semata melalui iman yang juga merupakan pemberian Allah. Meski demikian, di dalam presentasi-presentasi Trinitarian dalam surat Efesus, kita mendapat peran yang berbeda dari Bapa, Anak, dan Roh Kudus bagi pembentukan spritualitas umat-Nya. Dan ketiganya dibahasakan dengan ungkapan-ungkapan devosional (penyembahan) walau tidak disinggung mengenai status kesetaraan hakikat ketiga Pribadi tersebut sebagaimana yang di kemudian hari dirumuskan dalam konsili-konsili gerejawi. Dalam ulasan selanjutnya, kita akan menemukan mengapa Paulus belum membahas isu ini dalam kaitan dengan presentasi pola-pola triadiknya dalam surat Efesus.

\section{Perbandingan: Surat Efesus dan Injil Yohanes}

Karena bagian ini sekadar merupakan pointer untuk melihat kekhususan pola-pola triadik dalam surat Efesus, maka pembahasan mengenai pola-pola triadik dalam Injil Yohanes sebagai perbandingannya tidak akan dilakukan secara detail seperti yang sudah dilakukan sebelumnya. Saya hanya akan memberikan gambaran ringkasnya kemudian memperlihatkan kekhususan penggunaan pola-pola triadik dalam surat Efesus serta siginfikansinya bagi kepenulisan Paulus yang banyak ditolak di kalangan para sarjana critical.

Pertanyaannya adalah mengapa harus membuat perbandingan dengan Injil Yohanes? Seperti yang kita ketahui bersama, mayoritas sarjana menerima pandangan bahwa Injil Yohanes ditulis pada masa mendekati akhir abad pertama Masehi. Dua pakar Injil, D.A. Carson dan Douglas J. Moo mendiskusikan beragam usulan pandangan mengenai tahun penulisan Injil ini, mulai dari pandangan bahwa Injil ini ditulis sebelum tahun $70 \mathrm{M}$ hingga pandangan bahwa Injil ini ditulis pada quarter pertama abad kedua Masehi. Carson dan Moo menerima tahun 80-85 M sebagai tahun penulisan Injil Yohanes. ${ }^{153}$ Tanggal penulisan seperti ini akan memberikan kita suatu material perbandingan yang menarik antara isi Injil Yohanes dan Surat Efesus. ${ }^{154}$

Dalam Injil Yohanes, kita mendapat sejumlah bagian yang memperlihatkan pola triadik yakni mengenai Bapa, Anak, dan Roh Kudus dalam sejumlah narasi. Dalam narasi mengenai pembaptisan Yesus, Yohanes mencatat mengenai kehadiran Roh Kudus dan juga kata-kata "Ia inilah Anak Allah" yang bila dibandingkan dengan narasi-narais dalam Injil

152 Schreiner, Paul the Apostle of God's Glory in Christ: A Pauline Theology, 421.

153 Lih. Carson and Moo, An Introduction to the New Testament, 264-267.

154 Perbandingan antara pola-pola triadik dalam surat Efesus dan Injil Yohanes dilakukan juga oleh: Robert Letham, “Ternary Patterns in Paul's Letter to the Ephesians," in MJT 13 (2002): 69. 
Sinoptik merupakan kata-kata Bapa dari sorga (1:29-34; bnd. Mrk. 1:9-11; Mat. 3:13-17; Luk. 3:21-22). Dalam percakapan dengan Nikodemus, Yesus berbicara mengenai Roh dan Bapa (dengan menggunakan istilah "Allah"; 3:1-21).155

Selanjutnya, dalam Yohanes 14-17 kita mendapat pola triadik berupa refleksi yang mendalam antara hubungan antara Bapa, Anak, dan Roh Kudus. ${ }^{156}$ Dalam Yohanes 14, Yesus mempersiapkan para murid-Nya menjelang kematian-Nya dengan mengajarkan bahwa Ia akan meminta kepada Bapa untuk mengirimkan Roh Kudus guna menyertai mereka sebagai Penghibur. Roh ini "diutus oleh Bapa dalam nama-Ku" (ay. 26). Dalam pasal 15:18-27, Yesus berbicara mengenai dunia membenci para pengikut-Nya karena dunia telah terlebih dahulu membenci Dia. Namun, mereka yang membenci Dia juga adalah orang-orang yang "membenci Bapa-Ku". Mereka membenci "baik Aku maupun Bapa-Ku" (ay. 23, 24). Yesus melanjutkan mengenai Penghibur yang diutus Bapa yaitu Roh Kebenaran yang keluar dari Bapa, Ia akan bersaksi tentang Yesus (ay. 26). Dalam pasal 16, Yesus berbicara mengenai tugas atau pekerjaan Roh yang disebut sebagai Penghibur ketika Yesus kembali kepada Bapa. Dalam pasal 17, ketika mendoakan misi serta para pengikutNya, Yesus berbicara mengenai hubungan para pengikut-Nya dengan Bapa maupun DiriNya. Di dalam pasal ini, terdapat suatu penekanan yang kuat mengenai relasi yang intim antara Bapa dan Yesus. ${ }^{157}$ Akhirnya, sesudah bangkit dari kematian dan menampakkan diri-Nya kepada para murid, Yesus berbicara tentang pengutusan Bapa terhadap diri-Nya yang menjadi dasar pengutusan-Nya terhadap para murid, kemudian Ia mengembusi mereka dengan Roh Kudus (20:19-23). ${ }^{158}$

Kilasan gambaran mengenai pola-pola triadik dalam Injil Yohanes pada paragraf di atas, kita mendapati seperti yang ditulis oleh Butin bahwa baik dalam Injil Yohanes maupun dalam Surat Efesus, terdapat suatu kesadaran yang mencolok mengenai pola-pola triadik dan secara konstan (tetap) mendapatkan penekanan yang sangat kuat bila dibandingkan dengan bagian-bagian lain dalam PB yang hanya secara sporadis berbicara mengenai pola-pola triadik. ${ }^{159}$

Lebih dari itu, Letham memperlihatkan bahwa ada suatu tendensi yang agak berbeda dalam presentasi pola-pola triadik dalam Injil Yohanes dengan presentasi mengenai polapola triadik dalam surat Efesus. Letham menyatakan bahwa dalam Injil Yohanes, sudah terdapat indikasi mengenai upaya untuk memberikan refleksi teologis mengenai relasi ontologis antara Bapa, Anak, dan Roh Kudus khususnya dalam hubungan dengan monotheisme Yudaisme. Sementara dalam surat Efesus, tampaknya Paulus sekadar melontarkan mengenai peran yang berbeda dari Bapa, Anak, dan Roh Kudus tanpa membahas bagaimana hubungan keberadaan antara Bapa, Anak, dan Roh Kudus. ${ }^{160}$

Saya setuju dengan Letham karena kita sudah bisa mendeteksi upaya Yohanes mendemonstrasikan relasi ontologis Bapa dan Anak dalam bagian Prolognya. Yohanes menulis:

155 Philip Walter Butin, The Trinity (Louisville, Kentucky: The Westminster John Knox Press, 2001), 17.

156 Studi secara khusus mengenai Roh Kudus dalam Injil Yohanes, dilakukan oleh: George Johnston, The Spirit - Paraclete in the Gospel of John (Cambridge: Cambridge University Press, 1970). Sedangkan studi secara khusus mengenai Bapa dalam Injil Yohanes serta relasi-Nya dengan Yesus, dilakukan dalam: Adele Reinhartz (ed), God the Father in the Gospel of John (Atlanta: The Society of Biblical Literature, 1999).

157 Lih. Gary M. Burge, John (The NIVAC NT; Grand Rapids, Michigan: Zondervan, 2000), 459.

158 Lih. Donald K. McKim, Theological Turning Points: Major Issues in Christian Thought (Louisville, Kentucky: Westminster John Knox Press, 1988), 7.

159 Butin, The Trinity, 17-18.

160 Letham, "Ternary Patterns in Paul's Letter to the Ephesians," 69. 


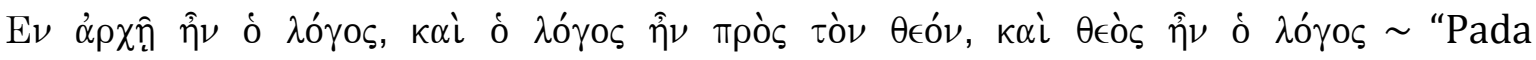
mulanya adalah firman, dan firman itu bersama-sama dengan Allah, dan firman itu adalah Allah." (Yoh. 1:1 Terjemahan saya).

Klausa pertama (Ev $\dot{\alpha} \rho \chi \hat{n} \hat{\eta} \nu$ ó $\lambda o ́ \gamma o \varsigma)$ menjelaskan kekekalan "firman" (Yesus; bnd. Yoh.

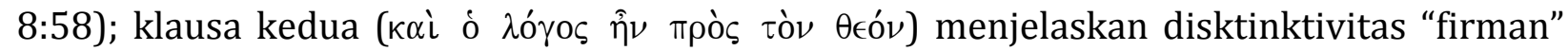

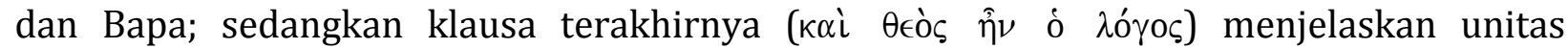
(kesatuan) kesetaraan "firman" dan Bapa (bnd. Yoh. 10:31). Daniel Wallace, seorang pakar Bahasa Yunani dan pakar Kritik Teks PB di Dallas Theological Seminary, mengomentari Yohanes 1:1 dalam kaitan dengan isu Trinitas, demikian:

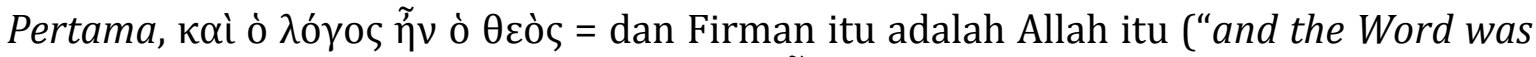

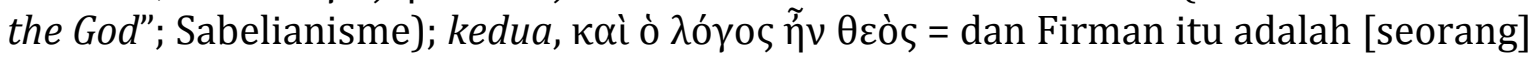

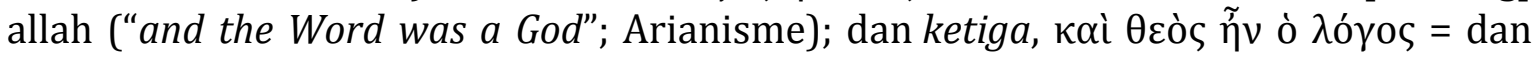
Firman itu adalah Allah ("and the Word was God"; Ortodoksi). ${ }^{161}$

Sebelum Wallace, Reformator terkemuka, Martin Luther, sudah berujar demikian mengenai Yohanes 1:1: "The lack of an definite article is against Sabellianism; the word order is against Arianism."162

\section{E. Praktik Penyembahan dan Devosi}

Sekarang kita akan beralih ke ulasan historis mengenai bagaimana praktik penyembahan dan devosi orang-orang Kristen mula-mula serta relasinya dengan monotheisme Yahudi kuno atau monotheisme Yahudi Bait Suci Kedua. Untuk itu, saya akan merujuk kepada hasil riset dari Larry W. Hurtado (New Testament scholar, historian of early Christianity and Emeritus Professor of New Testament Language, Literature and Theology at the University of Edinburgh) dan Richard Bauckham (Professor of the New Testament and a senior scholar at Ridley Hall, Cambridge University).

Hasil riset dari kedua sarjana kawakan di atas sangat penting untuk di bahas di sini karena, salah satunya yang terpenting adalah, menolong kita untuk menegaskan akar keyahudian dari Kekristenan mula-mula. Hal ini merupakan pokok fundamental mengingat tendensi para penganut "Aliran Sejarah Agama" (Ing. the history of religion school; Jerm. Religionsgeschichtliche Schule) yang cenderung percaya bahwa asal-usul Kekristenan harus di cari dalam politheisme Greco-Roman ketimbang monotheisme Yudaisme kuno. ${ }^{163}$

\section{Larry W. Hurtado: Pola Binitarian atau Pola Diadik}

Profesor Hurtado menulis cukup banyak buku dan artikel jurnal berkait Kekristenan mulamula dari sudut pandang penyelidikan sejarah. Dalam kaitannya dengan isu ini, saya akan membahas hasil riset Hurtado mengenai praktik penyembahan dan devosi dalam

161 Diulas dalam: William D. Mounce, Basic of Biblical Greek Grammar (2 ${ }^{\text {nd }}$ ed.; Grand Rapids, Michigan: Zondervan, 2003), 27-28.

162 Dikutip dalam: Mounce, Basic of Biblical Greek Grammar, 28.

163 Misalnya, karya klasik dari: Wilhelm Bousset, Kyrios Christos: A History of the Belief in Christ from the Beginning of Christianity to Irenaeus, trans. John E. Steely (Nashville: Abingdon Press, 1970). Bousset percaya bahwa PB mengajarkan Kristologi Tinggi (High Christology) atau bahwa Yesus dipresentasikan sebagai Allah dalam PB. Namun, Bousset percaya bahwa asal-usul keyakinan ini lebih berlatar belakang Hellenistik ketimbang berlatar belakang Yudaistik. Mengenai Aliran Sejarah Agama, lih. Werner Kümmel, The New Testament: The History of the Investigation of Its Problems, trans. G. McLean Gilmour and Howard C. Kee (Nashville: Abingdon, 1970). 
Kekristenan mula-mula. Namun sebelumnya, saya perlu mengawali bagian ini dengan memperlihatkan hasil riset Hurtado mengenai terminologi "monotheisme".

\section{a. Problem Terminologi: Monotheisme Yahudi Kuno}

Sebelum Hurtado, telah ada beberapa penulis yang mencurigai makna "monotheisme" dalam pengertian masa kini untuk dikenakan bagi karakter teologi Yahudi Bait Suci Kedua maupun Kekristenan mula-mula.

Pada tahun 1991, Peter Hayman mengklaim bahwa istilah "monotheisme" dalam pengertian modern: "Doktrin atau kepercayaan bahwa hanya ada satu Allah" (yang implikasinya menolak eksistensi allah-allah lain) merupakan sesuatu yang tidak dapat dikenakan bagi Yudaisme Bait Suci Kedua. Alasan paling mendasarnya adalah bahwa tidak ada bukti dari periode Bait Suci Kedua dimana orang-orang Yahudi menganut paham monotheisme dalam pengertian tersebut. Bahkan literatur-literatur Yahudi Bait Suci Kedua memperlihatkan adanya kepercayaan terhadap makhluk-makhluk sorgawi yang mereka gambarkan dengan ungkapan-ungkapan penghormatan yang mencolok, namun mereka tetap melihat keyakinan mereka sebagai keyakinan akan Allah yang esa. ${ }^{164}$

Pada tahun 2006, Paula Fredriksen menyerukan agar kita sama sekali tidak boleh lagi menggunakan istilah "monotheisme" untuk menggambarkan mengenai karakter teologis Yudaisme Kuno dan Kekristenan mula-mula. ${ }^{165}$ Istilah ini harus "undur diri" dari kosakata studi sejarah mengenai Yudaisme Bait Suci Kedua dan Kekristenan mula-mula. Ia mengklaim bahwa pengertian modern mengenai "monotheisme" sama sekali tidak terdapat dalam benak orang-orang Yahudi kuno dan orang-orang Kristen mula-mula. Mereka memang menegaskan keesaan Allah, namun penekanan mereka bukan pada penolakan akan eksistensi allah-allah lain, melainkan bahwa hanya Allah (Yahweh) yang layak menerima penyembahan dan devosi tertinggi. ${ }^{166}$

Hurtado menerima klaim dan argumen para pendahulunya di atas, namun ia tidak sependapat dengan Fredriksen yang menyerukan "pengunduran diri" istilah "monotheisme" dalam studi sejarah mengenai Yahudi kuno dan Kekristenan mula-mula. Hurtado percaya bahwa istilah tersebut masih bermanfaat untuk digunakan asalkan diberikan qualifier (istilah penjelas). Itulah sebabnya, ia memilih menggunakan istilah "monotheisme Yahudi kuno" (ancient Jewish monotheism). Dengan menggunakan istilah ini, ia tetap menekankan keesaan Allah yang merupakan karakter utama Yudaisme, namun qualifier-nya ("Yahudi kuno") secara langsung memberikan penerangang bahwa monotheisme yang dimaksud bukan monotheisme dalam pengertian modern, melainkan montheisme Yahudi kuno. ${ }^{167}$ Dalam konteks Greco-Roman yang politheistik, baik Yudaisme maupun Kekristenan di satu sisi tidak menyangkali eksistensi dewa-dewa tersebut, namun menganggapnya sebagai sesembahan-sesembahan yang tidak layak disembah (bnd. 1Kor. $10: 14-21) .168$

Saya diyakinkan oleh argumen dan bukti-bukti yang dipaparkan Hurtado, itulah sebabnya, mengikuti Hurtado, saya pun menggunakan istilah "monotheisme Yahudi kuno".

\section{b. Devosi Binitarian atau Diadik}

164 Peter Hayman, “Monotheisme - A Misused Word in Jewish Studies," JJS 42 (1991): 1-13.

165 Paula Fredriksen, "Mandatory Retirement: Ideas in the Study of Christian Origins Whose Time Has Come to Go," SR 35 (2006): 231-246.

166 Lih. Fredriksen, "Mandatory Retirement: Ideas in the Study of Christian Origins Whose Time Has Come to Go," 35.

167 Bnd. Sub-judul dari: Larry W. Hurtado, One God, One Lord: Early Christian Devotion and Ancient Jewish Monotheism (Edinburgh: T\&T Clark, 1998).

168 Hurtado, One God, One Lord: Early Christian Devotion and Ancient Jewish Monotheism, 129 n.1. 
Dalam bukunya yang berjudul: At the Origins of Christian Worship, Hurtado memperlihatkan adanya karakter atau pola binitarian atau pola diadik (dyadic pattern) dalam ekspresi penyembahan dan devosi dalam Kekristenan mula-mula. ${ }^{169}$ Kekristenan mula-mula "mengikutsertakan Kristus dan Allah (Bapa) sebagai penerima penyembahan." 170 Praktik ini sudah terlihat dalam dokumen terawal PB, yaitu Surat 1 Tesalonika, dimana Paulus menulis:

Sebab mereka sendiri berceritera tentang kami, bagaimana kami kamu sambut dan bagaimana kamu berbalik dari berhala-berhala kepada Allah untuk melayani Allah yang hidup dan yang benar, dan untuk menantikan kedatangan Anak-Nya dari sorga, yang telah dibangkitkan-Nya dari antara orang mati, yaitu Yesus, yang menyelamatkan kita dari murka yang akan datang. (1:9-10).

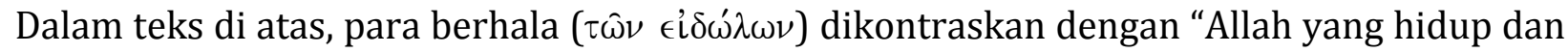

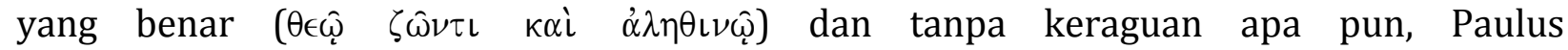
mengikutsertakan Yesus sebagai bagian dari pengharapan futuristik mereka. Sebelumnya, dalam ungkapan doksologisnya, Paulus menyatakan: "Dari Paulus, Silwanus dan Timotius kepada jemaat orang-orang Tesalonika yang di dalam Allah Bapa dan di dalam Tuhan Yesus Kristus. Kasih karunia dan damai sejahtera menyertai kamu." (1:1; bnd. 3:11-13; 5:9-10, 18).

Ia memang melihat adanya pola-pola triadik seperti yang sudah saya bahas dalam bagian sebelumnya yang di dalamnya melibatkan Roh Kudus, namun dari segi praktik penyembahan, Hurtado menegaskan: "Di dalam PB, penyembahan diberikan di dalam Roh Kudus, namun tidak jelas bahwa Roh Kudus dilihat sebagai penerima penyembahan."171

Guna menggambarkan maksud Hurtado dengan lebih jelas, saya ingin menarik perhatian kita kepada bagian terkenal dalam Yohanes 4:23-24 dimana Yesus berkata kepada perempuan Samaria itu bahwa akan tiba masanya dimana orang-orang akan menyembah Allah secara benar dengan penyembahan di dalam Roh dan kebenaran. Tetapi, bagian ini tidak menyatakan bahwa para penyembah yang benar itu akan menyembah Roh Kudus.

Memang ada satu bagian dalam surat Paulus yang memuat doksologi triadik: "Kasih karunia Tuhan Yesus Kristus, dan kasih Allah, dan persekutuan Roh Kudus menyertai kamu sekalian" (2Kor. 13:14). Tetapi, isi doksologi ini menegaskan tentang berkat-berkat Triadik bagi jemaat, bukan berbicara mengenai penyembahan yang berpola Triadik.

Di sisi lain, lontaran-lontaran mengenai penyembahan kepada Yesus yang sangat eksplisit dikemukakan, misalnya:

Itulah sebabnya Allah sangat meninggikan Dia dan mengaruniakan kepada-Nya nama di atas segala nama, supaya dalam nama Yesus bertekuk lutut segala yang ada di langit dan yang ada di atas bumi dan yang ada di bawah bumi, dan segala lidah mengaku: 'Yesus Kristus adalah Tuhan,' bagi kemuliaan Allah, Bapa! (Flp. 2:9-11). ${ }^{172}$

Dalam Roma 15:5-7, mengenai Kristus, Paulus menulis:

${ }^{169}$ Larry W. Hurtado, At the Origins of Christian Worship: The Context and Character of Earliest Christian Devotion (Grand Rapids, Michigan: Eerdmans, 1999).

170 Hurtado, At the Origins of Christian Worship: The Context and Character of Earliest Christian Devotion, 63.

171 Hurtado, At the Origins of Christian Worship: The Context and Character of Earliest Christian Devotion, 64.

172 Bagian lain yang sudah saya kutip sebelumnya, Matius 28:19 memang mengikutsertakan Roh Kudus bersama Bapa dan Anak, namun penekanan teks ini bukan soal objek penerima penyembahan, melainkan otentikasi praktik baptisan. 
Semoga Allah, yang adalah sumber ketekunan dan penghiburan, mengaruniakan kerukunan kepada kamu, sesuai dengan kehendak Kristus Yesus, sehingga dengan satu hati dan satu suara kamu memuliakan Allah dan Bapa Tuhan kita, Yesus Kristus. Sebab itu terimalah satu akan yang lain, sama seperti Kristus juga telah menerima kita, untuk kemuliaan Allah.

Perhatikan bahwa dalam bagian di atas, ketika berbicara mengenai penyembahan kepada Allah (Bapa), Paulus menyebut Yesus sebagai "Tuhan" (Yun. kúpıos). Dalam Roma 15, Paulus memang berbicara mengenai orang-orang percaya beroleh pengharapan yang berlimpah "oleh Roh" dan bahwa persembahan yang benar kepada Allah disucikan "oleh Roh Kudus" (ay. 13, 16), namun bagian ini tidak mengindikasikan Roh Kudus sebagai penerima penyembahan.

Juga dalam Wahyu 7:9-12, kita mendapati penyembahan kepada Allah (Bapa) dan Anak Domba (Yesus), namun tidak ada lontaran apa pun mengenai penyembahan kepada Roh Kudus:

Kemudian dari pada itu aku melihat: sesungguhnya, suatu kumpulan besar orang banyak yang tidak dapat terhitung banyaknya, dari segala bangsa dan suku dan kaum dan bahasa, berdiri di hadapan takhta dan di hadapan Anak Domba, memakai jubah putih dan memegang daun-daun palem di tangan mereka. Dan dengan suara nyaring mereka berseru: 'Keselamatan bagi Allah kami yang duduk di atas takhta dan bagi Anak Domba!' Dan semua malaikat berdiri mengelilingi takhta dan tua-tua dan keempat makhluk itu; mereka tersungkur di hadapan takhta itu dan menyembah Allah, sambil berkata: 'Amin! puji-pujian dan kemuliaan, dan hikmat dan syukur, dan hormat dan kekuasaan dan kekuatan bagi Allah kita sampai selama-lamanya! Amin!'

Akhirnya, bagian bagian terkenal lainnya yang digunakan Hurtado sebagai bagian dari judul bukunya, yaitu 1 Korintus 8:5-6,

Sebab sungguhpun ada apa yang disebut 'allah', baik di sorga, maupun di bumi dan memang benar ada banyak 'allah' dan banyak "tuhan" yang demikian namun bagi kita hanya ada satu Allah saja, yaitu Bapa, yang dari pada-Nya berasal segala sesuatu dan yang untuk Dia kita hidup, dan satu Tuhan saja, yaitu Yesus Kristus, yang oleh-Nya segala sesuatu telah dijadikan dan yang karena Dia kita hidup.

Hurtado melihat pola penyembahan yang binitarian itu, di satu sisi berkesinambungan dengan Yudaisme Kuno, yaitu penekanan akan keesaan Allah dan penolakan terhadap validitas penyembahan allah-allah lain dalam dunia Greco-Roman, namun di sisi lain, praktik penyembahan dalam Kekristenan mula-mula memperlihatkan sebuah "mutasi" (ketidaksinambungan) dengan Yudaisme kuno, yaitu bahwa mereka menyembah Yesus Kristus dan Allah (Bapa). Dalam kata-kata Hurtado sendiri, sikap religius orang-orang Kristen mula-mula "dibentuk oleh etos PL/Yahudi mengenai penolakan terhadap penyembahan kultis akan allah-allah lain, manusia, malaikat-malaikat, dan figur-figur lainnya."173 Namun secara "eksplisit dan programatik mereka mengikutsertakan Kristus di dalam praktik devosional mereka". ${ }^{174}$

Jadi dengan menggunakan istilah "mutasi" untuk menggambarkan fenomena penyembahan di atas, Hurtado hendak menyatakan bahwa monotheisme Yahudi kuno bisa disebut sebagai asal-usul devosi Kristen. Namun koneksi organik tersebut memiliki

173 Hurtado, At the Origins of Christian Worship: The Context and Character of Earliest Christian Devotion, 69-70.

174 Hurtado, At the Origins of Christian Worship: The Context and Character of Earliest Christian Devotion, 70 . 
distinktivitas mendasar dalam penyembahan Kristen mula-mula yang layak mendapat label yang lain, yaitu "monotheisme Kekristenan mula-mula" dengan devosi binitarian sebagai karakteristiknya. ${ }^{175}$

Akhirnya, poin penting lain dari riset Hurtado yang perlu dikemukakan di sini adalah penolakannya terhadap teori evolusi Kristologis dimana para penganut Aliran Sejarah Agama percaya bahwa pemujaan terhadap Yesus berevolusi secara perlahan hingga mencapai bentuknya yang matang dalam Konsili Nicea. Secara tegas Hurtado menolak pandangan ini, dengan menyatakan bahwa pola penyembahan yang binitarian itu sudah muncul pada masa Paulus menulis surat-suratnya yang merupakan dokumen-dokumen terawal PB. Artinya, pola penyembahan ini merupakan karakteristik dalam jemaat-jemaat Kristen yang digembalakan maupun yang kepada mereka Paulus menuliskan suratsuratnya. Hal ini sangat mungkin sudah dimulai sejak masa-masa awal setelah penyaliban Yesus. Dan karena itu, pola penyembahan ini tidak dapat dianggap terjadi melalui sejumlah tahap evolusi yang lamban. ${ }^{176}$

\section{Richard Bauckham: Kristologi Identitas Ilahi}

Sekarang kita akan beralih ke hasil riset Profesor Bauckham yang dipublikasikan melalui buku berjudul: Jesus and the God of Israel. ${ }^{177}$ Berbeda dengan Hurtado yang memberikan perhatian khusus terhadap praktik penyembahan dan devosi dalam Kekristenan mulamula, Bauckham fokus untuk membuktikan bahwa latar belakang Kristologi Tinggi (High Christology) dalam PB ada pada monotheisme Yahudi kuno.

Dalam bab berjudul: "Biblical Theology and the Problems of Monotheism," Bauckham juga mendiskusikan mengenai problem penggunaan terminologi "monotheisme" sebagaimana yang sudah di bahas di atas. Senada dengan itu, Bauckham mencatat bahwa "monotheisme" yang sekarang kita gunakan dan pahami maknanya, tidak lebih dari sebuah warisah Pencerahan (Enlightenment) yang akan menjadi sebuah kesalahan kategori jika kita terapkan makanya untuk berbicara mengenai Yudaisme kuno. ${ }^{178}$

Selanjutnya, Bauckham mencatat bahwa ada dua fitur distinktif dalam Yudaisme Bait Suci Kedua khususnya dalam retorika teologis mereka mengenai Allah yang membedakanNya dari allah-allah dari bangsa-bangsa lain. Bertolak dari Shema dan Dekalog, juga elaborasi-elaborasinya dalam literatur-literatur Yahudi Bait Suci Kedua, Bauckham melihat bahwa mereka berbicara tentang identitas ilahi (divine identity) dalam dua kategori spesifik, yaitu bahwa Allah adalah Pencipta atas segala sesuatu dan bahwa Allah berdaulat atas segala sesuatu. ${ }^{179}$ Bauckham menulis,

Allah Israel adalah satu-satunya Pencipta segala sesuatu dan Tuhan yang berdaulat atas segala sesuatu. Dari antara segala sesuatu yang dikatakan mengenai Allah dalam periode Yahudi Bait Suci Kedua, dua aspek dari relasi unik-Nya dengan segala kenyataan yang lain, merupakan aspek-aspek yang paling umum dikutip, dan secara berulang digunakan untuk menempatkan YHWH pada kategori yang unik. Mayoritas penulis Yahudi tidak ragu-ragu untuk memperjelas bahwa dalam pengertian ini,

\footnotetext{
175 Lih. Hurtado, One God, One Lord: Early Christian Devotion and Ancient Jewish Monotheism, 93-124.

176 Lih. Larry W. Hurtado, Lord Jesus Christ: Devotion to Jesus in Earliest Christianity (Grand Rapids, Michigan: Eerdmans, 2003), 153.

177 Richard Bauckham, Jesus and the God of Israel: God Crucified and Other Studies on the New Testament's Christology of Divine Identity (Epub version; Grand Rapids, Michigan: Eerdmans, 2008).

178 Bauckham, Jesus and the God of Israel: God Crucified and Other Studies on the New Testament's Christology of Divine Identity, Chp. 2: Biblical Theology and the Problems of Monotheism.

179 Bauckham, Jesus and the God of Israel: God Crucified and Other Studies on the New Testament's Christology of Divine Identity, loc., 91/228.
} 
YHWH adalah satu-satunya Allah yang benar dan harus diakui demikian oleh semua orang. ${ }^{180}$

Dengan menekankan kedua aspek di atas sebagai cara untuk menegaskan keunikan identitas YHWH, Yudaisme Bait Suci Kedua menolak segala macam penyembahan yang bukan kepada YHWH sebagai penyembahan berhala. Alasannya jelas yaitu bahwa mereka memberikan penyembahan kepada objek-objek yang tidak layak menerima penyembahan tersebut. Hanya YHWH yang layak disembah karena hanya Dialah yang telah menciptakan segala sesuatu dan berdaulat atas segala sesuatu. ${ }^{181}$ Mereka sering menggambarkan hal ini dengan menggunakan ungkapan "takhta Allah" (the throne of God). ${ }^{182}$

Setelah menetapkan premis di atas, Bauckham berargumentasi bahwa pemujaan atau penyembahan terhadap Yesus dalam PB dengan kategori-kategori identitas ilahi (mis. Yoh. 1:3; Kol. 1:15-17; Mat. 28:18; Mat. 26:64; Luk. 22:69; Kis. 7:55-56; Rm. 8:34; Kol. 3:1; Ibr. $1: 3 ; 8: 1 ; 10: 12$; $12: 2$; 1 Pet. $3: 22$; merupakan sesuatu yang sangat fenomenal. ${ }^{183}$ Atau, meminjam analogi dari B.B. Warfield, Kristologi Tinggi dalam PB ibarat seperti air laut dimana Anda tidak perlu membuktikan keasinannya dengan hanya merujuk kepada bongkahan-bongkahan garam tertentu. ${ }^{184}$

Meski demikian, Kristologi Tinggi yang sangat fenomenal dalam PB tersebut harus dilihat sebagai sesuatu yang tidak bertentangan tetapi justru sebaliknya kompetibel dengan pandangan Yudaisme Bait Suci Kedua mengenai identitas ilahi. Bauckham menulis,

Kunci untuk melihat monotheisme Yahudi dan Kristologi Tinggi saling berkompetibel dalam gerakan Kekristenan mula-mula adalah bukan dengan klaim bahwa monotheisme Yahudi meninggalkan ruang bagi figur-figur semi-ilahi, melainkan kesadaran akan pemahaman monotheisme Yahudi mengenai identitas unik dari Allah yang esa meninggalkan ruang bagi termasuknya Yesus di dalam identitas tersebut. Meskipun langkah ini belum pernah ada sebelumnya, namun karakter monotheism Yahudi tidak membuat langkah ini tidak mungkin. ${ }^{185}$

Dengan melihat upaya para penulis PB untuk mengikutsertakan Yesus dalam kategori-kategori identitas ilahi yang eksklusif milik Yahweh dalam Yudaisme Bait Suci Kedua, Bauckham menyebutnya sebagai Kristologi Identitas Ilahi.

\footnotetext{
180 Bauckham, Jesus and the God of Israel: God Crucified and Other Studies on the New Testament's Christology of Divine Identity, loc., 54/228.

181 Bauckham, Jesus and the God of Israel: God Crucified and Other Studies on the New Testament's Christology of Divine Identity, 54/228.

182 Bauckham, Jesus and the God of Israel: God Crucified and Other Studies on the New Testament's Christology of Divine Identity, Chp. 5: The Throne of God and the Worship of Jesus.

183 Mis. seruan "Maranatha" (1Kor. 6:22; bnd. Why. 22:20; Did. 10:6); doa-doa yang ditujukan kepada Yesus (2Kor. 12:8; 1Tes. 3:11-13; 2Tes. 2:16-17; 3:5, 16; bnd. Rm. 16:20b; 1Kor. 16:23; Gal. 6:18; Flp. 4:23; 1Tes. 5:28; 2Tes. 3:18; Flm. 25); orang-orang Kristen adalah mereka yang memanggil 'nama Tuhan kita Yesus Kristus' (1Kor. 1:2; bnd. Rm. 10:12-14; Kis. 9:14, 21; 22:16; 2Tim. 2:22) - sebuah frasa yang tidak diragukan lagi berasal dari Yoel 2:32 (Kis. 2:21; Rm. 10:13) yang dalam PL secara regular digunakan untuk penyembahan kepada YHWH (Kej. 4:26; 12:8; 13:4; Mzm. 105:1); doksologi-doksologi (Rm. 16:27; 2Tim. 4:18; 2Pet. 3:18 Yud. 25; Why. 1:5-6; bnd. 2Kor. 1:20; 1Pet. 4:10); himne-himne (Flp. 2:6-11; 1Tim. 3:16; bnd. 1Kor. 14:26; Kol. 3:16; Ef. 5:19). Belum termasuk teks-teks mengenai Yahweh dalam PL yang diaplikasikan oleh para penulis PB bagi Yesus (mis. 1Kor. 1:2; Rm. 10:13 - Yl. 2:32; Zef. 3:9; Za. 13:9; Yer. 10:25; dll.) mengenai daftar teks-teks Yahwe tersebut dalam PB, lih. Bauckham, Jesus and the God of Israel: God Crucified and Other Studies on the New Testament's Christology of Divine Identity, 109/228.

184 Lih. Benjamin B. Warfield, "The Deity of Christ," in R.A. Torrey, A.C. Dixon, et al (eds.), The Fundamentals: A Testimony to the Truth (Los Angeles: Bible Institute of Los Angeles, 1917), 2:239-46.

185 Bauckham, Jesus and the God of Israel: God Crucified and Other Studies on the New Testament's Christology of Divine Identity, loc., 105/228.
} 


\section{Kesimpulan}

Seperti yang kita ketahui bersama bahwa rumusan yang baku mengenai relasi Bapa, Anak, dan Roh Kudus yang kemudian terkenal dengan rumusan: "Tiga Pribadi Satu Hakikat", baru dilakukan dalam Konsili Nicea (325 M) dan Konsili Konstatinopel (381 M). Dan seperti yang sudah diperlihatkan dalam ulasan di atas pula bahwa tampaknya, relasi ontologis dari Bapa, Anak, dan Roh Kudus, lebih dapat diinferensi dari Injil Yohanes ketimbang surat Efesus.

Meski demikian, surat Efesus memberikan kontribusi bagi perkembangan formulasi doktrin Tritunggal secara khusus berdasarkan beberapa poin teologis di bawah ini:

a. Pola-pola triadik dalam surat Efesus, secara kuat memberikan fondasi pemahaman bahwa rencana keselamatan sepenuhnya adalah karya Allah sejak kekekalan hingga kekekalan. Dan dalam rencana keselamatan ini, terdapat keterlibatan atau peran yang berbeda dari Bapa, Anak, dan Roh Kudus. ${ }^{186}$

b. Pola-pola triadik dalam surat Efesus menghadirkan gagasan teologis bahwa pengetahuan atau pengenalan akan Allah yang sejati hanya dapat terjadi atas inisitif Allah sendiri yang membuka akses itu melalui pengorbanan Kristus dan kemudian diefektifkan bagi orang-orang percaya melalui karya Roh Kudus. ${ }^{187}$

c. Pola-pola triadik dalam surat Efesus memberikan penekanan kuat bahwa keselamatan itu sepenuhnya adalah karya Allah yang hanya dapat diterima sebagai kasih karunia semata melalui iman yang juga adalah pemberian Allah. ${ }^{188}$

d. Pola-pola triadik dalam surat Efesus memperlihatkan bahwa rekonsiliasi penebusan yang terjadi antara orang-orang berdosa dengan Allah serta rekonsiliasi sosial yang terjadi dalam menghancurkan sekat-sekat etnis (relasi Yahudi-non Yahudi) merupakan hasil dari karya Bapa, Anak, dan Roh Kudus. ${ }^{189}$

e. Pola-pola triadik dalam surat Efesus memberikan penekanan teologis bahwa gereja atau jemaat mendapatkan eksistensinya berdasarkan karya Kristus dan pekerjaan Roh Kudus sehingga gereja menjadi umat Allah yang kudus dan hidup sesuai dengan kehendak-Nya. ${ }^{190}$

f. Pola-pola triadik dalam surat Efesus juga memberikan penekanan bahwa pembentukan spiritualitas orang-orang percaya mendapatkan kuasa, daya tahan, serta kemampuannya untuk mengalahkan Si Jahat, juga oleh karena peran sentral dari Bapa, Anak, dan Roh Kudus. ${ }^{191}$

Implikasinya, kita sudah bisa mendapatkan basis dari surat Efesus bahwa terdapat tiga Pribadi yang berbeda dengan peran yang berbeda walau tanpa elaborasi mengenai bagaimana relasi ontologis di antara ketiga Pribadi tersebut. ${ }^{192}$

Untuk itu, perlu diringkas kembali beberapa gagasan inti yang penting dalam seluruh uraian di atas, yaitu:

a. PB secara konsisten memaklumatkan bahwa Allah adalah Esa, namun pada saat yang sama memberikan presentasi-presentasi keallahan dalam pola rangkap tiga.

186 Robert L. Reymond, A New Systematic Theology of the Christian Faith (2 ${ }^{\text {nd }}$ and revised edition; Nashville, Tennessee: Thomas Nelson, 1998), 250-252.

187 Reymond, A New Systematic Theology of the Christian Faith, 253.

188 Reymond, A New Systematic Theology of the Christian Faith, 253-254.

189 Reymond, A New Systematic Theology of the Christian Faith, 254.

190 Reymond, A New Systematic Theology of the Christian Faith, 254-255.

191 Reymond, A New Systematic Theology of the Christian Faith, 255.

192 Mengenai kesadaran akan pola-pola triadik dalam bagian-bagian lain PB, lih. Butin, The Trinity, 18; Don Garlington, "Biblical Reflection on the Doctrine of the Trinity," in Reformation and Revival, Vol. 10, No. 3 (2001): 21-22; Kenneth R. Samples, Without a Doubt: Answering the 20 Thoughest Faith Questions (Grand Rapids, Michigan: Baker, 2004), 69-70. 
Hal ini sangat mendominasi PB, yang dalam Studium Generale ini saya khususkan ulasannya pada Surat Efesus. Donald Guthrie, tidak lama sebelum kematiannya, menyatakan: "Bisa dikatakan bahwa Paulus tidak bekerja dengan kerangka konseptual yang secara natural memimpin kepada spekulasi-spekulasi tentang esensi Allah.... Namun bukti-bukti dalam surat-suratnya meletakkan dasar bagi doktrin yang dikembangkan kemudian hari. Masalah-masalah yang dihadapi oleh doktrin yang muncul itu memiliki akar masalahnya dalam PB sendiri."193

b. Surat-surat Paulus sebagai dokumen-dokumen terawal PB, tampaknya belum mencapai tahap refleksi teologis sebagaimana yang terdapat dalam Injil Yohanes, yaitu tahap pertimbangan akan kaitan ontologis antara Bapa, Anak, dan Roh Kudus, dan bagaimana hal ini sesuai dengan monotheisme Yahudi kuno.

c. Cara Paulus mempresentasikan himne atau kredo dalam Efesus 4:4-6 dengan menunjuk kepada pola trenari atau pola triadik, memperlihatkan bahwa ini merupakan keyakinan yang secara mendalam dianutnya sehingga ia merasa perlu memberikan elaborasi ekstensif, karena pola triadik ini telah dikenal secara luas, jika tidak universal, di antara para pembacanya.

d. Pola triadik atau pola trenari ini bukan hanya tampak begitu jelas, melainkan juga terungkap dalam semua bagian penting dari surat Efesus. Pola triadik ini ada di semua bagian, bisa dikatakan demikian. Dengan demikian, pola triadik atau pola trenari mendasari semua yang Paulus katakan, baik tentang rencana keselamatan dan implementasinya, pengetahuan kita akan Allah, atau mengenai Gereja. Pola triadik atau pola trenari itu juga berhubungan erat dengan akibat-akibat praktis dari iman Kristen, yang diungkapkan dalam kesatuan gereja dan dalam bagaimana orang-orang percaya berinteraksi satu sama lain.

Bisa dikatakan, sebagai kesimpulan berbasis elaborasi-elaborasi eksegetis di atas, bahwa pola-pola triadik merupakan pusat teologi Paulus dalam Surat Efesus. Di sisi lain, dari segi praktik penyembahan dan devosinya, Kekristenan mula-mula tampaknya didominasi oleh pola penyembahan yang binitarian atau diadik (seperti argumentasi Hurtado). Apakah Roh Kudus disembah dalam praktik penyembahan dan devosi Kekristenan mula-mula? Bukti-bukti dari PB memaksa kita untuk menahan diri dalam memberikan jawaban positif terhadap pertanyaan ini. Hal ini tidak berarti bahwa Roh Kudus tidak dipresentasikan sebagai Allah (bnd. Yoh. 14-16; dll.), namun memang objek penerima penyembahan dan devosi dalam halaman-halaman PB didominasi oleh Bapa dan Anak. Pola penyembahan ini, mendapatkan latar belakangnya bukan dalam agama-agama Greco-Roman, melainkan dalam monotheisme Yahudi kuno. Dari monotheisme Yahudi kuno juga, kita mendapati acuan bagi Kristologi identitas ilahi yang sangat dominan dalam PB (Bauckham).es

\section{Referensi}

Renihan, James M., Associational Churchmanship: Second London Confession of Faith 26.1215, Volume 2 of Recovering Our Confessional Heritage, Palmdale, CA.: Reformed Baptist Academic Press, 2016.

Grudem, Wayne, Systematic Theology: An Introduction to Biblical Doctrine, Epub Version; Grand Rapids, Michigan: Zondervan, 1994.

Bavinck, Herman, Reformed Dogmatics, Volume Two: God and Creation, trans. John Vriend, Epub Version; Grand Rapids, Michigan: Eerdmans, 2004.

Dunzl, A Brief History of the Doctrine of the Trinity in the Early Church.

193 Donald Guthrie, "God," in in Dictionary of Paul and His Letters, eds. Gerald F. Hawthorne, Ralph P. Martin, and Daniel G. Reid (Software Version; Downers Grove, Illinois: InterVarsity Press, 1993). 
Daley, Brian E., Gregory of Nazianzus, London and New York: Routledge, 2006.

McGrath, Alister E., Christian Theology: An Introduction, Epub version; $5^{\text {th }}$ ed.; West Sussex: Blackwell Publishing, Ltd., 2011.

Grondin, Jean, “Augustine's 'Si Comprehendis, Non Est Deus': To What Extent Is God Incomprehensible?," Analecta Hermeneutica, Vol. 9 (2017): 1-13.

Letham, Roberth, Allah Trinitas dalam Alkitab, Sejarah, Theologi, dan Penyembahan, terj. Lanna Wahyuni, Surabaya: Momentum, 2004.

V. Synan, "Pentecostalism," in Walter A. Elwell (ed.), Evangelical Dictionary of Theology, Grand Rapids, Michigan: Baker, 1995.

Erickson, Millard J., Christian Theology, Epub version; 3 ${ }^{\text {rd }}$ ed.; Grand Rapids, Michigan: Baker Academic, 2013.

Adamec, Ludwig W., Historical Dictionary of Islam (2nd ed.; Lanham: Scarecrow Press, Inc., 2009).

Ibrahim, Raymond, Crucified Again: Exposing Islam's New War on Christians, Washington, DC.: Regnery Publishing, Inc., 2013.

Spencer, Robert, The Truth about Muhammad: The Founder of the World's Most Intolerant Religion, Washington, DC: Regnery Publishing, Inc., 2006.

White, James R., What Every Christian Needs to Know about the Qur'an, Minneapolis, Minnesota: Bethany Publishing House, 2013.

Dunn, Did the James D.G., First Christians Worship Jesus?The New Testament Evidence, Louisville, Kentucky: Westminster John Knox Press, 2010.

Erickson, Millard J., Making Sense of the Trinity: 3 Crucial Questions, Epub version; Grand Rapids, Michigan: Baker Academic, 2000.

Metzger, Bruce M., A Textual Commentary on the Greek New Testament (4th ed.; New York: American Bible Society, 2002).

Dunn, James D.G., Christology in the Making: An Inquiry into the Origins of the Doctrine of the Incarnation, $2^{\text {nd }}$ ed.; London: SCM Press, 1989.

Carson, D.A., Jesus the Son of God: A Christological Title Often Overlooked,Sometimes Misunderstood, and Currently Disputed, Epub version; Wheaton, Illinois: Crossway Books, 2012.

Thielman, Frank, The Theology of the New Testament: A Canonical and Synthetic Approach, Grand Rapids, Michigan: Zondervan, 2005.

Dunn, James D.G., The Theology of Paul, Grand Rapids, Michigan: Eerdmans, 1998.

Vos, Geerhardus, Biblical Theology: Old and New Testaments ( $7^{\text {th }}$ ed.; Grand Rapids, Michigan: Eerdmans, 1971.

Smith-Christopher, Daniel L., A Biblical Theology of Exile: Overtures to Biblical Theology, Minneapolis: Fortress Press, 2002.

Carson D.A., and Douglas J. Moo, An Introduction to the New Testament, $2^{\text {nd }}$ ed.; Grand Rapids, Michigan: Zondervan, 2005.

Arthur W. Wainwright, The Trinity in the New Testament, London: SPCK, 1962.

William J. Larkin, Ephesians: A Handbook on the Greek Text, Waco, Texas: Baylor University Press, 2009.

Ralph P. Martin, Ephesians, Colossians, Philemon, Interpretation: A Bible Commentary for Teaching and Preaching; Atlanta: John Knox Press, 1973.

William Hendriksen, Galatians and Ephesians, New Testament Commentary; Edinburgh: The Banner of Truth Trust, 1969.

John P. Heil, Ephesians: Empowerment to Walk in Love for the Unity of All in Christ, Leiden: Brill, 2007.

Crawford, Leslie J., "Ephesians 1:3-4 and the Nature of Election," in The Master's Seminary Journal 11/1 (2000): 75-91. 
Fee, Gordon D., God's Empowering Presence: The Holy Spirit in the Letters of Paul, Peabody, MA.: Hendrickson, 1994.

Kitchen, Martin, Ephesians, New Testament Readings; London: Routledge, 1994.

Pannenberg, Wolfart, Systematic Theology, trans. Geoffrey W. Bromiley, Grand Rapids, Michigan: Eerdmans, 1991), 1.326.

Snodgrass, Klyne, Ephesians, The NIV Application Commenary of the NT; Grand Rapids, Michigan: Zondervan, 1996.

Hoehner, Harold, Ephesians: An Exegetical Commentary, Grand Rapids, Michigan: Baker, 2002.

Fee, Gordon D., Pauline Christology: An Exegetical-Theological Study, Peabody, MA.: Hendrickson, 2007.

Hendrikson, Galatians and Ephesians, 37; bnd. Max Turner, "Ephesians," in G.J. Wenham, et al (eds), New Bible Commentary, 21 $1^{\text {st }}$ Century Edition; Downers Grove, Illinois: IVP Academic, 2007.

Ridderbos, Herman, Paulus: Pemikiran Utama Theologinya, terj. Hendry Ongkowidjojo, Surabaya: Momentum, 2008.

Mare, W. Harold, "Paul's Mystery in Ephesians 3," in Bulletin of the Evangelical Theological Society 8.2 (1980): 77-84.

Kostenberger, Andreas J., "What Does It Mean to be Filled with the Spirit? A Biblical Investigation," in Journal of Evangelical Theological Society 40.2 (June 1997): 230231.

Easley, K. H., "The Pauline Usage of Pneumati as a Reference to the Spirit of God," in Journal of Evangelical Theological Society 27 (1984): 299-313.

Schreiner, Thomas R., Paul the Apostle of God's Glory in Christ: A Pauline Theology, Downers Grove, Illinois/Leicester: IVP/Apolos, 2001.

Gombis, Timothy B., "Being the Fullness of God in Christ by the Spirit: Ephesians 5:18 in Its Epistolary Setting," in Tyndale Bulletin 53.2 (2002): 259-271.

Butin, Philip Walter, The Trinity, Louisville, Kentucky: The Westminster John Knox Press, 2001.

Burge, Gary M., John, The NIVAC NT; Grand Rapids, Michigan: Zondervan, 2000.

McKim, Donald K., Theological Turning Points: Major Issues in Christian Thought, Louisville, Kentucky: Westminster John Knox Press, 1988.

Mounce, William D., Basic of Biblical Greek Grammar, 2 ${ }^{\text {nd }}$ ed.; Grand Rapids, Michigan: Zondervan, 2003.

Hurtado, Larry W., At the Origins of Christian Worship: The Context and Character of Earliest Christian Devotion, Grand Rapids, Michigan: Eerdmans, 1999.

Bauckham, Richard, Jesus and the God of Israel: God Crucified and Other Studies on the New Testament's Christology of Divine Identity, Epub version; Grand Rapids, Michigan: Eerdmans, 2008.

Guthrie, Donald, "God," in in Dictionary of Paul and His Letters, eds. Gerald F. Hawthorne, Ralph P. Martin, and Daniel G. Reid, Software Version; Downers Grove, Illinois: InterVarsity Press, 1993. 